\title{
Multiple Identification Foci and Their Countervailing Effects on Salespeople's Negative Headquarters Stereotypes
}

Using a large-scale, multilevel data set, this study introduces to the sales management literature the concept of sales representatives' headquarters stereotypes as a negative outcome of social identification. The results suggest that work team identification fosters headquarters stereotyping more strongly when organizational identification is low than when it is high. Salespeople's physical distance from their corporate headquarters increases work team identification and decreases organizational identification. Competitive intensity, as an external threat to salespeople's social identity, strengthens stereotyping and social identification. In addition to important theoretical implications, this research also provides crucial insights for managers. Headquarters stereotypes are critically important because they can have harmful consequences for sales performance and customer satisfaction. Key managerial implications are that managers should foster organizational identification and that using different compensation systems does not remedy the negative effects of stereotypes.

Keywords: stereotypes, identification, dispersed sales teams, competitive intensity, sales performance

$\mathbf{T}$ he psychological literature thoroughly documents the finding that people define themselves at least partly in terms of the groups to which they belong (Ashforth and Mael 1989; Ellemers, De Gilder, and Haslam 2004; Tajfel and Turner 1986). The process by which a group becomes directly linked to its members' sense of self is referred to as social identification (Shamir and Kark 2004).

Viewing identification as a root construct in organizations (Albert, Ashforth, and Dutton 2000), scholars have shown in numerous studies that employee-company identification leads people to act on behalf of their organization, resulting in a variety of positive outcomes for the organization, such as increased organizational citizenship behavior (OCB) and better performance (Celsi and Gilly 2010; Dukerich, Golden, and Shortell 2002; Larson et al. 2008; Olkkonen and Lipponen 2006; Van Knippenberg and Van Schie 2000). Similarly, research has shown customer-company identification to be a predictor of customer loyalty and customer willingness to pay (Ahearne, Bhattacharya, and Gruen 2005; Homburg, Wieseke, and Hoyer 2009). Given these positive out-

Jan Wieseke is Professor of Marketing (e-mail: jan.wieseke@ rub.de), and Sven Mikolon is a postdoctoral student in Marketing (e-mail: sven. mikolon@rub.de), Ruhr-University Bochum. Florian Kraus is Professor of Marketing, University of Mannheim, and Dr. Werner Jackstädt Endowed Chair of Business Administration and Marketing IV and Research Fellow, C.T. Bauer College of Business, University of Houston (e-mail: kraus@ bwl.uni-mannheim.de). Michael Ahearne is Professor of Marketing and Executive Director, Sales Excellence Institute, C.T. Bauer College of Business, University of Houston (e-mail mahearne@uh.edu). All authors contributed equally to this article. Author order was decided by coin flips. comes, marketing and management scholars have typically viewed social identification as desirable.

However, virtually no research has investigated the potential negative consequences of social identification processes in organizations. This lack of attention is surprising, given the fundamental prediction of social identity theory that identification associated with in-groups drives negative stereotypes of out-groups (Tajfel and Turner 1986). Indeed, in their seminal article, Ashforth and Mael (1989, p. 20) note that "social identification leads to ... stereotypical perceptions of self and others." Stereotypes can be a powerful predictor of negative or even antisocial intergroup behavior, such as discrimination against the targeted group (e.g., Caprariello, Cuddy, and Fiske 2009; Cuddy, Fiske, and Glick 2007; Heilman and Okimoto 2008). Therefore, inattention to the role of negative stereotypes is a major shortcoming of previous research on social identification processes in organizations.

Organizations are especially prone to intergroup stereotyping because they provide their members with multiple group memberships for constructing their social identities, such as the shift, the work team, the department, or, more holistically, the entire organization (Homburg et al. 2011). All groups represent possible identification foci for their members (Ashforth, Harrison, and Corley 2008; Van Knippenberg and Van Schie 2000) and at the same time are potential targets for intergroup stereotyping. As a result, stereotyping and its detrimental behavioral outcomes, such as scapegoating, aggression, or lack of support for the targeted group, are apparently ubiquitous in most organizations (for reviews on behavioral outcomes of stereotypes, 
see Hewstone, Rubin, and Willis 2002; Hilton and Von Hippel 1996).

Furthermore, because employees can simultaneously identify with different groups (Ashforth and Johnson 2001; Olkkonen and Lipponen 2006) and given that identification with in-groups drives out-group stereotyping (Tajfel and Turner 1986), intergroup stereotypes are a likely subject of the interplay between different identification foci within organizations, such as the work team and the organization as a whole. Indeed, identifications with different targets in the workplace can be complicated and place conflicting demands on people (Hekman et al. 2009). Complications may arise particularly for employees working in distributed teams that are, to a certain extent, distant from their corporate headquarters. Such conditions can undermine organizational identification and foster fierce subgroup loyalty through identification with more localized groups (Cradador and Pratt 2006). However, the negative consequences of multiple identifications remain largely unexplored, and empirical research in this stream has not yet considered stereotypes as a negative identification outcome.

The current study investigates sales representatives' stereotyping of their corporate headquarters. The corporate headquarters are particularly likely to be negatively stereotyped because they represent a ubiquitous, high-status group that possesses multiple interfaces with other organizational subgroups (Ashforth and Mael 1989; Reade 2001). Furthermore, according to the literature, at least two lines of evidence demonstrate that headquarters stereotypes are particularly important in sales management. First, although neglecting the constructs of identification and stereotyping, literature on the "thought worlds" of organizational subunits shows that sales teams occupy a somewhat unique thought world within organizations (Homburg and Jensen 2007). Therefore, sales teams may develop a differentiated and unique in-group identity that fosters fierce subgroup loyalty, intergroup comparisons, and, subsequently, outgroup stereotyping (Ashforth and Mael 1989; Haslam and Ellemers 2005). This identity may particularly characterize dispersed sales teams.

Second, in a personal selling setting, salespeople are the face of an organization (Hartline, Maxham, and McKee 2000), and they pervasively affect customers' perceptions of the entire company through their direct interaction (Ahearne, Bhattacharya, and Gruen 2005; Liao and Chuang 2004). Thus, salespeople harboring negative headquarters stereotypes may evoke unfavorable customer evaluations of the company that subsequently affect organizational performance.

The present study has three purposes. First, by empirically linking the concept of stereotypes with social identification, we shed light on potentially harmful organizational outcomes of social identification processes and address an important empirical research gap. This contribution is particularly consequential because organizations are highly differentiated systems and stereotypes can explain a variety of intergroup contexts. Second, whereas previous research has predominantly examined only the organizational identification of salespeople, this study investigates both their organizational and work team identification simultaneously and reveals countervailing effects of these identifications on headquarters stereotypes. Adopting a multiple identity perspective seems to be particularly fruitful for research dealing with salespeople working in dispersed sales teams, because previous investigators have argued that such conditions foster identification with the localized identity focus and threaten identification with the organization as a whole (Cradador and Pratt 2006). Third, the study investigates how an external threat to a social identity in the form of perceived competitive intensity affects salespeople's social identification and headquarters stereotyping. Despite its importance to social identification processes, research on social identity threats is still in its infancy, and our results provide important theoretical implications.

For the present study, we collected data from 1548 salespeople in 299 sales districts across two divisions of a large U.S.-based company in the business-to-business sector. We rely on the notion of "nested identities" and base our model on sales representatives' simultaneous identification with their organization and their work teams. Our results show that physical distance between salespeople's work teams and the corporate headquarters fosters work team identification and diminishes organizational identification. Our investigation further reveals that work team identification contributes most strongly to the prevalence of headquarters stereotypes when organizational identification is low rather than when it is high. Headquarters stereotypes, in turn, decrease sales performance and customer satisfaction with the sales interaction. Importantly, we find that different compensation systems (commission based vs. fixed salary) cannot deflect these negative effects of headquarters stereotyping. Furthermore, our findings show that competitive intensity fosters identification at both the work team and organizational levels and also directly strengthens headquarters stereotypes.

\section{The Phenomenon of Social Identification in Organizations}

\section{Social Identity and Social Identification in Organizations}

The social identity approach, which encompasses the theories of social identity (Hogg and Abrams 1988; Tajfel and Turner 1979) and self-categorization (Turner et al. 1987), proposes that a person's sense of identity is partly a function of belonging to a social group. In general, social identity is viewed as "that part of an individual's self-concept which derives from his knowledge of his membership of a social group (or groups) together with the value and emotional significance attached to that membership" (Tajfel 1978, p. 63).

Three features of this definition stand out. First, social identity is socially constructed and comparative in nature because it emerges from social categories and contains information about the positional status of the particular group and relevant comparison groups. Thus, a social identity is shared by group members, distinguishes groups (Ashforth, Harrison, and Corley 2008), and provides "the frame of reference for differentiation and social comparisons" (Brewer 1991, p. 476). Second, social identity is self-referential or 
self-defining (Pratt 1998) because people use it to describe themselves. Third, social identity implies a hedonic element because it comprises the emotional involvement with the group in question. In summary, social identity provides "a place in the social world" (Simon and Klandermans 2001, p. 320) and answers two fundamental self-defining questions: "Who am I?" and "How does it feel to be me?"

Social identification, as a related but distinct concept to social identity, is the process by which a group becomes directly linked to a person's self-concept (Shamir and Kark 2004). Thus, the degree of a person's identification with a specific group reflects the importance of a social identity for the person (Ashforth and Mael 1989; Olkkonen and Lipponen 2006). More specifically, identification refers to "a relatively enduring state that reflects an individual's readiness to define him- or herself as a member of a particular social group" (Haslam 2001, p. 383; for a review of the history of the construct, see Edwards 2005). Most important, while an organization simultaneously provides multiple group memberships for the person, the relative degree to which this person views each of the identities as selfdescriptive is a function of his or her identification with the given groups (Ellemers, De Gilder, and Haslam 2004). For example, depending on their level of work team identification and organizational identification, some employees may consider themselves members of a given work team first and foremost and organization members second, whereas for others the opposite might be true (Hekman et al. 2009; Johnson et al. 2006).

From a social identity perspective, motives for identification may include self-enhancement (Tajfel and Turner 1979) and uncertainty reduction (Hogg 2000). According to social identity theory, in general, people strive to maintain or enhance their self-esteem and therefore identify with social groups that possess favorable value connotations (Tajfel and Turner 1986). People tend to identify with groups they perceive as distinct and attractive because these groups enhance members' self-esteem (Ashforth and Mael 1989; Sluss and Ashforth 2008). Moreover, Tajfel and Turner (1986, p. 16) stress this self-enhancement function of social identification, stating that "identifications ... define the individual ... as 'better' or 'worse' than members of other groups."

In addition, uncertainty identity theory, which is an extension of social identity theory, maintains that a person's identification with a group can also be an aversive reaction to perceived uncertainty arising from the person's social context (Hogg 2000). Indeed, research in social psychology shows that subjective uncertainty is one of the most important motives for social identification (Grieve and Hogg 1999; Hogg et al. 2007).

When people identify with a social group, they tend to act and feel in congruence with salient aspects of their social identities (Edwards 2005), resulting in numerous positive behaviors on behalf of groups that embody their social identities (Ashforth and Mael 1989; Ellemers, De Gilder, and Haslam 2004). In organizational contexts, social identification thus motivates people to adopt several desirable behaviors, such as OCB (Dukerich, Golden, and Shortell 2002; Olkkonen and Lipponen 2006), organizational commitment (Meyer, Becker, and Van Dick 2006), and increased performance (Van Knippenberg 2000).

\section{Multiple Nested Social Identities in Organizations}

A growing body of empirical evidence supports the notion that when members of organizations construe their social identities, they may rely on multiple group memberships simultaneously (e.g., Hekman et al. 2009; Olkkonen and Lipponen 2006; Reade 2001; Van Dick et al. 2004; Van Knippenberg and Van Schie 2000). For example, employees can simultaneously identify with their work team and their organization as a whole. These multiple organizational identities, in turn, are hierarchically nested, with lowerorder identities embedded within higher-order identities (Ashforth, Harrison, and Corley 2008; Ashforth and Johnson 2001). Importantly, the literature on nested identities converges on the notion that, in general, organizational members are likely to identify more strongly with lowerorder identities than with higher-order identities (Ashforth and Johnson 2001; for meta-analytic support, see Riketta and Van Dick 2005).

The organizational consequences of the outcomes of multiple nested identities are often discrete and textured (Ashforth, Harrison, and Corley 2008). Previous research on the outcomes of simultaneous identifications with higher- and lower-order identities indicates that higherorder identification is more strongly related to specific higher-order outcomes, whereas lower-order identification is more strongly associated with specific lower-order outcomes (Riketta and Van Dick 2005). For example, Riketta and Van Dick's (2005) meta-analysis reveals that work team identification is more strongly related to outcomes on the work team level (e.g., work team extra-role behavior), whereas organizational identification is more strongly associated with outcomes on the organizational level (e.g., organizational extra-role behavior). Thus, although multiple nested forms of social identification might be correlated, to a certain extent, they are also independent (Van Dick et al. 2008).

\section{Multiple Nested Identities and Negative Outcomes for the Organization}

Identifications with different targets in the workplace can be complicated and impose conflicting demands on people (Hekman et al. 2009; Pratt and Foreman 2000). For example, research using a sample of physician employees showed that work performance is most negative when physicians' professional identification is high and their organizational identification is low (Hekman et al. 2009). Similarly, research in management indicates that group members can refuse to act on behalf of their organization if they think that doing so will threaten their lower-order identities (Alvesson and Willmot 2002; Ashforth and Mael 1998; Fisher, Maltz, and Jaworski 1997).

The key implication of this stream of research is that because people tend to act on behalf of the social identity that is most important for their self-concept, detrimental outcomes on the organizational level are more likely to arise when people identify more strongly with the lower- 
order identity. For example, employees who more strongly identify with their work team than with their organization might adhere to a work team goal that consists of covering up for colleagues' mistakes, though this practice is likely to conflict with a total quality strategy, which would be beneficial to the organization as a whole (Ulrich et al. 2007).

\section{Social Identification and Stereotypes in Organizations}

Defining stereotypes. Stereotypes are beliefs about the characteristics, attributes, and behaviors of members of certain groups (Hilton and Von Hippel 1996) and are most often overgeneralized and rigid (Krueger et al. 2008). Stereotypes can be based on an exaggeration of actual group differences (Swim 1994) and can occur even in the absence of actual group differences (Hamilton and Gifford 1976; Stroessner and Plaks 2001). Importantly, even stereotypes based on actual group differences are overgeneralized and exaggerated, reflecting a biased reality (Haslam and Turner 1992). Thus, regardless of their basis, stereotypes lead to conceptions of groups that diverge from reality (Macrae and Bodenhausen 2000). These conceptions evolve into a stereotypical belief system that people use to judge incoming information about out-groups (Bargh, Chen, and Burrows 1996; Cuddy, Fiske, and Glick 2007) and use as a basis for intergroup discriminations (Caprariello, Cuddy, and Fiske 2009; Heilman and Okimoto 2008).

Linking social identification and stereotypes. The social identity approach, comprising social identity theory (Tajfel 1978; Tajfel and Turner 1979) and its cognitive derivate selfcategorization theory (Turner et al. 1987), provides a theoretical framework for explaining the link between social identification and intergroup stereotyping. Self-categorization theory maintains that when people identify with groups, they categorize themselves as in-group members (with the ingroup containing the self) and others as out-group members. As a consequence, people perceive out-group members in terms of the stereotypes about their groups and not in terms of their characteristics as individual people (Ashforth and Mael 1989; Tajfel and Turner 1986). For example, categorizing someone as elderly is automatically associated with stereotypical expectations for this category, such as walking slowly. Therefore, according to self-categorization theory, stereotypes convey social information and are inevitably intertwined with social categorization processes (for a review of the self-categorization perspective on stereotyping, see Van Knippenberg and Dijksterhuis 2000).

In addition to self-categorization theory, social identity theory contributes a motivational explanation for why intergroup stereotyping occurs. More specifically, social identity theory maintains that when identified with a group, members actively try to enhance their sense of self by comparing their own in-group with relevant out-groups. For example, motivated by self-enhancement, people tend to denigrate out-group members after the out-group has lost status (Leach et al. 2003). These intergroup comparisons tend to be biased in favor of the person's own in-group. As a result, negative out-group stereotypes arise, which the person can mobilize against the out-group to gain a positive social identity for the in-group.

Taken together, the social identity approach offers both a cognitive (self-categorization) and a motivational (selfenhancement) explanation for why intergroup stereotyping occurs when a person has come to identify with a given group. Most important, the social identity approach proposes a direct link between social identification and intergroup stereotypes, fostering negative behaviors such as discrimination against out-groups (Caprariello, Cuddy, and Fiske 2009; Cuddy, Fiske, and Glick 2007; Heilman and Okimoto 2008).

Corporate headquarters as a potential target group for stereotyping. Negative intergroup stereotypes in organizations may mutually arise between any organizational subgroups. In general, however, negative stereotypes are likely to develop toward comparison groups that are enduringly salient and of high status in organizational contexts. Theoretical support for this notion comes from Ashforth and Mael (1989, p. 30): “A low-status group (such as noncritical staff function or cadre of middle managers) may go to great lengths to differentiate itself from a high-status comparison group (such as critical line functioning or senior management)." Complementing this view, social psychology has shown upward comparisons to more efficiently satisfy selfimprovement motives (Taylor, Neter, and Wayment 1995). Therefore, the corporate headquarters, as a ubiquitous group within a firm, may be particularly subject to negative stereotyping by other organizational groups.

\section{Conceptual Framework and Hypotheses}

In this section, we derive formal, testable hypotheses. We conceptualize headquarters stereotypes as the focal construct in our framework, and we hypothesize that physical distance between sales representatives' work teams and their corporate headquarters fosters work team identification and discourages organizational identification. Furthermore, we assume that either identification's effect on headquarters stereotypes depends on the strength of the other. Thus, we derive no direct effects of the two identifications on headquarters stereotypes. We propose that sales representatives' work team identification fosters headquarters stereotypes more strongly when organizational identification is low than when it is high. Moreover, we hypothesize that an external threat to sales representatives' social identity, in the form of perceived competitive intensity, addresses two fundamental motives of the social identity approach and therefore fosters both work team and organizational identification and strengthens headquarters stereotypes. Finally, we propose a direct negative link between negative headquarters stereotypes and the business outcomes of customer satisfaction with sales interaction and sales performance. We derive no hypothesis for separate direct effects of organizational identification and work team identification on headquarters stereotypes because a nested identity model assumes that sales representatives hold both identifications simultaneously. We also do not explicitly 
hypothesize direct effects of organizational or work team identification on outcomes, because such hypotheses represent no incremental insights with respect to prior research.

Testing our hypotheses regarding sales performance and customer satisfaction with the sales interaction requires accounting for variables that previous studies have found to be influential. Thus, we controlled for sales representatives' sales experience (for reviews, see Quiñones, Ford, and Teachout 1995; Sturman 2003), job satisfaction (e.g., MacKenzie, Podsakoff, and Ahearne 1998), commitment (for a meta-analysis, see Riketta and Van Dick 2005), customer orientation (for a meta-analysis, see Franke and Park 2006), organizational trust (e.g., Doney and Cannon 1997), OCB (Podsakoff and Mackenzie 1994), and leader-member exchange (LMX) (Graen and Uhl-Bien 1995). Moreover, we controlled for salespeople's perception of control systems, which can be either outcome or behavior based (Anderson and Oliver 1987; Oliver and Anderson 1994). Under outcome-based control systems, salespeople's compensation usually depends on their overall sales (Anderson and Oliver 1987), and the salesperson's objective is to allocate efforts to maximize overall sales. Under a behaviorbased control system, however, the salesperson's compensation and career progression largely depend on following directions provided by the firm, creating incentives for sales representatives to pursue a firm's nonsales goals, such as service and customer satisfaction. A behavior-based control system works in favor of a long-term perspective. Therefore, we assume a positive effect of a behavior-based control system on customer satisfaction, because this outcome is a longer-term one. In contrast, in the short run, sales performance might be harmed by the behavior-based control system. Figure 1 provides an overview of the proposed hypotheses.

Physical distance from corporate headquarters and social identification. Previous research in the context of virtual work (Wiesenfeld, Raghuram, and Garud 1999, 2001) and conceptual work in marketing has suggested that geographically dispersed working conditions can threaten and ultimately decrease organizational identification (Cradador and Pratt 2006; Wiesenfeld, Raghuram, and Garud 1999) and, at the same time, foster identification with more inclusive and proximal identities (Scott 1997), such as work teams. Construal-level theory (e.g., Henderson 2009; for a review, see Trope and Liberman 2003) and the social identity approach offer explanations of these relationships. Construallevel theory holds that people adopt different levels of representation or construal as a function of their temporal or physical distance to objects and events. According to this theory, temporal or physical distance can lead to an associa-

FIGURE 1

\section{Conceptual Framework}

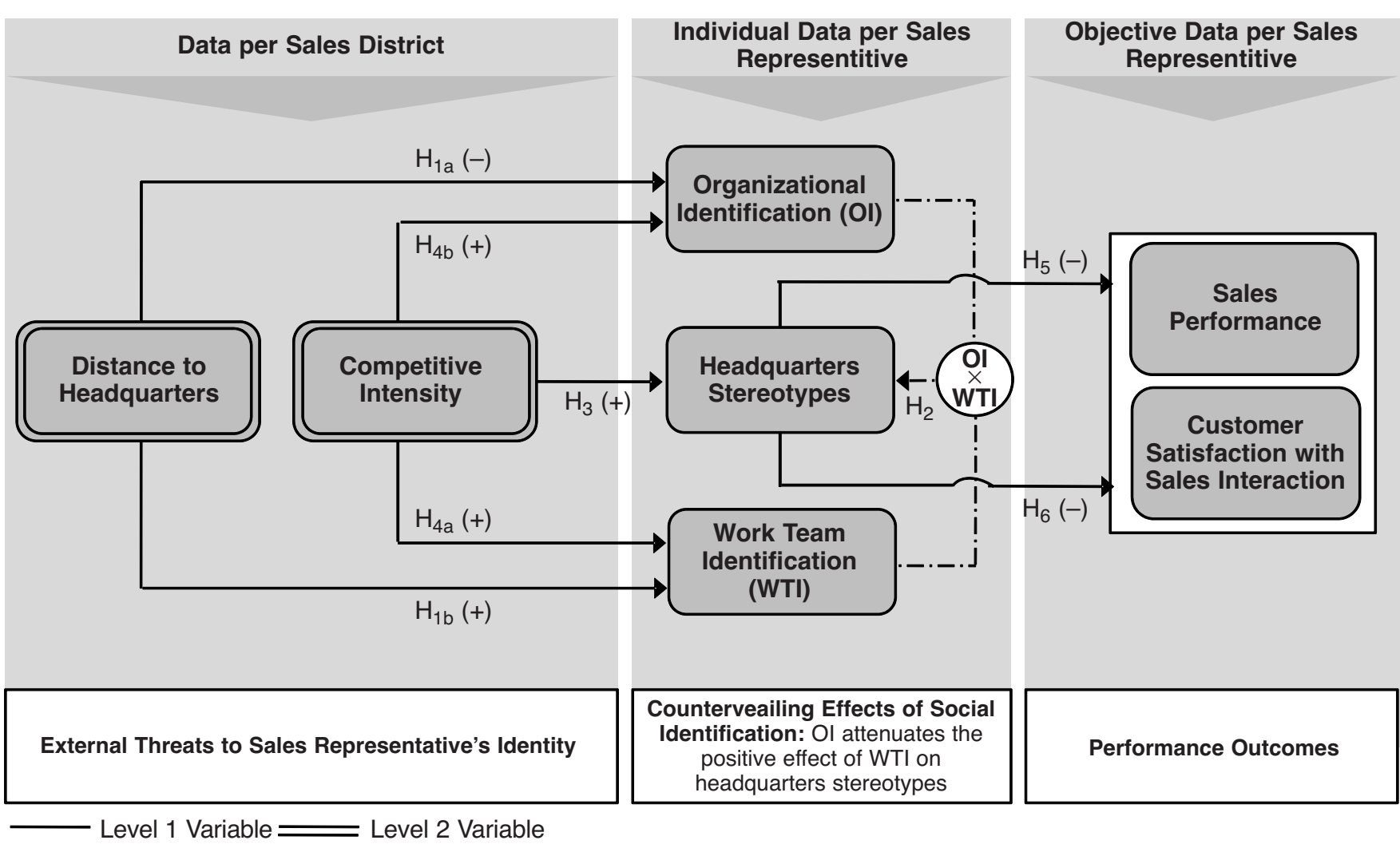

Notes: We also controlled for the direct effect of competitive intensity and organizational and team identification on sales performance and customer satisfaction. We also controlled for the direct effects of work team identification and organizational identification on headquarters stereotypes as well as for the direct effect of distance to headquarters on headquarters stereotypes. For reasons of simplicity, the direct effects and additional controls are not depicted in the figure. 
tion between distance and construal, such that more proximal objects trigger lower levels of construal (involving rich, concrete, and idiosyncratic information), whereas more distant objects trigger higher levels of construal (involving rather abstract information) (Fujita et al. 2006; Henderson 2009). For example, Fujita et al. (2006) provide evidence that greater physical distance indeed leads to a more abstract construal of social events.

The social identity approach holds that people tend to identify with groups they perceive as distinct and attractive because these groups enhance members' self-esteem (Ashforth and Mael 1989; Sluss and Ashforth 2008). Distinctiveness differentiates a given group from other groups and provides a sharp and salient definition of what the group signifies (Mael and Ashforth 1992). The prediction of construal-level theory that more distant objects trigger more abstract construal suggests that for sales representatives, organizational distinctiveness is likely to blur with increased physical distance between a sales team and the corporate headquarters. This is because idiosyncratic information about what the organization makes distinct and attractive as a target for sales representatives' identification is missing. Instead, the organizational identity remains rather distal, potentially leading people to feel psychologically lost in an abstract and large entity. Thus, with increasing physical distance, the organizational identity becomes less attractive as a target for sales representatives' identification.

In contrast, given a basic human need for identification (Ashforth, Harrison, and Corley 2008), to the extent that the organizational identity becomes less attractive as an identification target, the work team as a localized and concrete identity becomes more so. This shift occurs because the work team is the organizational unit in which people conduct most of their day-to-day job activities (Van Dick et al. 2008). More specifically, with increasing physical distance, people will progressively transfer identification from the organization to the work team. This reasoning leads to the following hypotheses:

$\mathrm{H}_{1}$ : The greater the physical distance, (a) the lower is sales representatives' organizational identification, and (b) the higher is sales representatives' work team identification.

Social identification and headquarters stereotypes. Employees can simultaneously hold multiple nested identities, such as with their organization and their work team (Bartel et al. 2007; Johnson et al. 2006; Olkkonen and Lipponen 2006). The extent to which people perceive each of these identities as self-descriptive is reflected by a person's identification with the given group (Ellemers, De Gilder, and Haslam 2004; Haslam and Ellemers 2005). Therefore, depending on their level of identification, some employees may consider themselves members of their work team first and of the organization second, whereas for others the opposite might be true (Hekman et al. 2009; Johnson et al. 2006).

We propose that headquarters stereotypes should be particularly prominent when members identify strongly with their work teams, as a relatively exclusive organizational domain, and only weakly with their organization. In this case, self-categorization theory predicts that identification sharpens group boundaries and enhances "us-versus-them" feelings between sales representatives' work teams and their corporate headquarters (Mael and Ashforth 1992). Thus, sales representatives perceive the corporate headquarters more strongly in terms of the stereotypes surrounding the headquarters (Ashforth and Mael 1989; Tajfel and Turner 1986).

Furthermore, according to the motivational perspective of social identity theory, when sales representatives identify with their work teams, the comparative nature of social identity encourages intergroup differentiation from important comparison groups. This differentiation is motivated by work team members striving for a more positive social identity (Brown and Hewstone 2005; Tajfel and Turner 1979). In the case of strong work team identification, sales representatives tend to comply with the self-enhancement demands of their work teams and will try to favorably compare with other groups, even at the expense of the entire organization. When organizational identification is low and work team identification is high, comparison groups are located at the organizational subgroup level (Richter et al. 2006), making the corporate headquarters a likely target for stereotyping.

Conversely, to the extent that sales representatives identify more strongly with the organization as the most inclusive and highest-order identity, work teams will use headquarters stereotypes less for regulating and interpreting intergroup relationships with the corporate headquarters (Ellemers, De Gilder, and Haslam 2004; Van Knippenberg and Dijksterhuis 2000). In this case, team members direct their attention to the inclusive organizational domain and minimize their attention to category differences between the work team and the corporate headquarters (Richter et al. 2006). For example, if a member of a sales team is highly identified with the holistic organization, subgroup categorizations - for example, into the sales team and the corporate headquarters - will be less important, and stereotypes attached to them will become less diagnostic for organizing social information (Ellemers 1993). Indeed, previous research in social psychology supports this notion. Employees who identify strongly with their work team (in this case, the higher-order identity) and to some extent with their ethnic group (in this case, the lower-order identity) have more harmonious relationships with other groups than those who do not identify with the higher-order identity (Huo et al. 1996).

Likewise, when sales representatives' identification with their organization is the most important identity domain for their sense of self, they tend to act on behalf of the entire organization. As a result, headquarters stereotypes will become less strong because this contributes to favorable intergroup relationships between the sales teams and the corporate headquarters, which ultimately is beneficial to the entire organization. In addition, in the case of strong organizational identification and weak work team identification, the motive for self-enhancement leads to favorable comparisons with other organizations and decreases comparisons with other organizational subgroups, such as the corporate headquarters.

Similarly, headquarters stereotypes should weaken when sales representatives hold a complex social identity 
(Roccas and Brewer 2002) and identify equally with both nested identities - the work team and the organization. A complex social identity leads sales representatives to classify the corporate headquarters in terms of multiple, more differentiated, and nonstereotypical dimensions and identify at least some similarities between work teams and the headquarters, which result from membership in the same organization (Hewstone et al. 2001). Thus, sales representatives perceive that the corporate headquarters and their own work teams share some common characteristics. This perception should lessen us-versus-them feelings and reduce headquarters stereotypes. Consistent with this contention, research has shown that intergroup bias diminishes when members of different social categories that are nested in a higherorder category are aware that they all share this higherorder category membership (Crisp and Hewstone 2000; Hewstone, Islam, and Judd 1993; Hewstone et al. 2001).

Finally, previous research on multiple nested identities has shown that equally high identification with nested groups contributes to members' self-consistency and leads to positive outcomes, such as motivation and individual well-being (Van Dick et al. 2008), ultimately resulting in a reduced desire for self-enhancement. From this reasoning, we hypothesize the following:

$\mathrm{H}_{2}$ : Sales representatives' work team identification has a stronger, more positive relationship with headquarters stereotypes when organizational identification is low than when it is high.

Threat to a positive social identity, key motives for social identification, and ambivalent effects on intraorganizational stereotyping. With one exception (Elsbach and Kramer 1996), social identity studies have only recently begun to investigate how people construct a positive social identity in the face of identity threats at work. According to Elsbach and Kramer (1996), identity threats can represent symbolic and sensemaking dilemmas for organization members because they call into question the merit or importance of core, distinctive, and enduring organizational traits associated with their institutions (Elsbach and Kramer 1996). In the face of threats, people begin to manage their identities more actively (Bartel 2001). At the same time, group members are likely to turn more strongly to their in-groups (Mael and Ashforth 1992). Thus, identity threats may facilitate cohesion in dispersed organizations and may therefore also have functional aspects, which marketing research has yet to explore.

From a social identity perspective, external identity threats stimulate key motives for social identification, selfenhancement (Tajfel and Turner 1979), and uncertainty reduction (Hogg 2000). Following Dutton and Jackson's (1987) definition, an external threat to a group presents a potentially negative situation, arising from the environmental context in which the group acts. The situation is negative because it involves potential loss for the group and comprises elements of surprise and novelty (Chattopadhyay, Glick, and Huber 2001; Dutton and Jackson 1987). Therefore, as uncertainty-identity theory predicts, external threats can induce feelings of uncertainty, enhancing people's social identification with in-groups (Hogg 2000, 2008). At the same time, a threat may refute a group's attractiveness and may call a person's social identity into question (Elsbach and Kramer 1996; Sluss and Ashforth 2008). In this case, the self-enhancement motive of social identity theory predicts that members will engage in compensatory behaviors aimed at restoring their sense of self.

When applied to the organizational subgroup level, this line of thinking suggests that external identity threats may have ambivalent effects. External threats enhance organizational identification (DiSanza and Bullis 1999; Elsbach and Kramer 1996), which should decrease headquarters stereotyping. However, the self-enhancement motive suggests that external threats should directly increase headquarters stereotypes to the extent that they challenge the favorability of the work team identity.

Competitive intensity and headquarters stereotypes. Social identity theory maintains that to satisfy self-enhancement needs, in general, people are motivated to favorably compare their own in-group with relevant comparison groups (Tajfel and Turner 1986). As empirical research in social psychology suggests, a particularly effective way to favorably compare the in-group with the out-group is to negatively stereotype the out-group (Branscombe and Wann 1994), especially when the in-group's relative status is at stake and the favorability of members' social identity is threatened (Branscombe and Wann 1994; Vignoles and Moncaster 2007). Because people generally need to evaluate themselves favorably (Tajfel and Turner 1986), a threatened social identity will trigger compensatory behaviors such as scapegoating or stereotyping. For example, research in social psychology has shown that when group members perceive that their in-group's ethics are threatened, they engage in compensatory behaviors such as out-group derogation and devaluation to restore in-group favorability (Branscombe and Wann 1994; Doosje, Ellemers, and Spears 1995; Ellemers and Bos 1998). Furthermore, a series of experimental studies shows that a threat to a positive social identity can result in increased discrimination against out-groups, whereas self-affirmation can impair discrimination (Fein and Spencer 1997).

From a sales management perspective, this evidence suggests that the work team can positively contribute to salespeople's sense of self when the team has prestige and high status. However, high competitive intensity poses a major threat to organizations because it implies the potential loss of resources for the firm (e.g., in terms of customers, turnover, sales growth), resulting in cost cutting and budget tightening (Thomas, Clark, and Gioia 1993). This threat also implies a loss of sales for salespeople (Keaveney 1995) and therefore has the potential to jeopardize salespeople's organizational prestige and status and subsequently their self-image. Conditions of high competitive intensity threaten the adequacy and worthiness of membership in an organizational sales team, and the value of this identity is at stake. Thus, high competitive intensity creates difficulty for salespeople to maintain positive images of themselves and their fellow group members and therefore poses a major threat to sales representatives' identities. 
Consistent with the logic of the aforementioned selfenhancement motive, in the face of a threatened social identity (e.g., intense competition), salespeople should adopt strategies to compensate for this threat. As we outlined previously, theoretical and empirical evidence suggests that stereotyping a relevant comparison group is a particularly effective way to resolve identity crises and protect the favorability of the social identity. In line with our previous contention, for salespeople, the corporate headquarters serves as a relevant comparison group. Thus, we propose the following:

\section{$\mathrm{H}_{3}$ : The greater the perceived competitive intensity, the stronger are the sales representatives' negative headquar- ters stereotypes.}

Competitive intensity and social identification. On the individual level, competitive intensity is especially threatening for sales representatives. Salespeople acting under conditions of high competitive intensity face customers who have many options for satisfying their needs and wants (Jaworski and Kohli 1993). Complementing this view, Keaveney (1995) shows that attraction by superior competitors is a fundamental predictor of customer switching behavior. As a consequence, salespeople perceive they have less control over their selling performance, which increases their feelings of uncertainty (Chandrashekaran et al. 2000).

According to uncertainty-identity theory, social identification with groups can be conceived of as a reaction to subjectively perceived uncertainty (Hogg 2000, 2008). Social identification is a particularly effective way to reduce uncertainty because classifying the self and others into social categories renders the self's and others' behavior predictable (Bartel 2001; Hogg 2008). Consequently, highly identified group members benefit from socially derived certainty. In addition, research in social psychology suggests that socially derived certainty in one life domain can compensate for uncertainty in another domain (McGregor and Marigold 2003; McGregor et al. 2001). Thus, high competitive intensity should be positively related to identification due to uncertainty reduction.

Finally, social identity maintains that people engage in supportive behavior on behalf of the groups embodying their social identities (Ashforth and Mael 1989; Ellemers, De Gilder, and Haslam 2004; Tajfel and Turner 1986). Furthermore, people expect to receive protection and support from their in-groups (their work team and their organization) and are therefore likely to band together with similar others in the face of external threats.

People can simultaneously identify with more than one organizational group (Hogg and Abrams 1988; Olkkonen and Lipponen 2006). Because competitive intensity poses an equal threat to sales representatives' work team identification and organizational identification, the fundamental processes leading to identification would seem to apply equally to both identities. Therefore, we hypothesize the following:

\footnotetext{
$\mathrm{H}_{4 \mathrm{a}}$ : The greater the perceived competitive intensity, the stronger are the sales representatives' (a) work team identification and (b) organizational identification.
}

Negative headquarters stereotypes and sales representatives' sales performance. Research in social psychology shows that stereotypes lead to discrimination against targeted groups (Caprariello, Cuddy, and Fiske 2009; Correll et al. 2002; Cuddy, Fiske, and Glick 2007; Heilman and Okimoto 2008). Discrimination can take various forms, ranging from active aggression (e.g., explicitly aiming to hurt an out-group) to passive harm (e.g., disregarding the needs of out-groups) (Cuddy, Fiske, and Glick 2007).

A corollary of this empirical evidence is that sales representatives holding strong negative headquarters stereotypes should be unwilling to adopt sales innovations and comply with sales guidelines put in place by corporate headquarters (e.g., for a review of factors leading to sales force automation use, see Jones, Sundaram, and Chin 2002). This unwillingness should result in lower sales performance (Ahearne, Srinivasan, and Weinstein 2004; Rapp, Agnihotri, and Forbes 2008).

Furthermore, if stereotypes lead to discrimination toward the group in question, sales representatives holding negative headquarters stereotypes should put less effort into their selling activities, either because they lack motivation or because they become motivated to actively violate normative expectations of their headquarters. Given that effort is a key antecedent of sales performance (Brown and Peterson 1994; Christen, Iyer, and Soberman 2006; Sujan, Weitz, and Kumar 1994), its absence should affect sales performance adversely. From this reasoning, we hypothesize the following:

$\mathrm{H}_{5}$ : The stronger the sales representatives' negative headquarters stereotypes, the lower is the sales representatives' sales performance.

Negative headquarters stereotypes and customer satisfaction with the sales interaction. In their role as boundary spanners, sales representatives link an organization to its customers (Ahearne, Bhattacharya, and Gruen 2005; Bitner, Booms, and Mohr 1994). Regarding customers' satisfaction with the frontline employee, which can be defined as a customer's overall evaluation of the interaction with the sales representative (Gustafsson, Johnson, and Ross 2005), customer interaction research has shown that customers hold expectations about how a boundary-spanning agent should perform his or her role within the interaction (Bitner, Booms, and Mohr 1994). When sales representatives meet customer expectations regarding role behavior, the result is satisfaction with the sales interaction (Bitner, Booms, and Mohr 1994; Oliver 1980). Sales representatives' negative statements or behaviors that are based on stereotypes will instigate negative customer perceptions of the interaction, disconfirm role expectations, and subsequently lead to lower levels of satisfaction.

In support of this proposition, research in social psychology suggests that stereotypes are communicated and transmitted between people. For example, Stephan and Stephan (1984) show that educators pass their stereotypes on to their pupils. Most important, this transmission can even happen without the conscious intent of the one harboring the stereotypes (Devine 1989; Monteith, Devine, and Zuwerink 1993). The main implication is that if sales repre- 
sentatives possess negative stereotypes of their corporate headquarters, they are likely to make negative statements about their corporate headquarters when interacting with customers. Customers will then directly perceive stereotypes in the organization and experience sales representatives as acting on the basis of their stereotypes. These perceptions are contrary to their expectations and should lead to decreased satisfaction.

Furthermore, psychological research indicates that members of in-groups tend to describe relevant out-groups more stereotypically and with more negative affect than their own in-group (Harasty 1997). Plausibly, then, when interacting with customers, sales representatives harboring negative stereotypes will show more negative emotions than sales representatives possessing less negative stereotypes. According to emotional contagion theory (Barsade 2002), the negative emotions salespeople display will spill over to their customers and decrease enjoyment of the personal interaction (Hennig-Thurau et al. 2006). Because customers also tend to form expectations about the level of positive affect related to the interaction, this spillover should lead to decreased satisfaction.

$\mathrm{H}_{6}$ : The stronger the sales representatives' negative headquarters stereotypes, the lower is customer satisfaction with the sales interaction.

\section{Method}

\section{Sample}

Research context. We collected data from the sales force of a U.S.-based Fortune 500 company in the cleaning and sanitizing industry. The sales representatives surveyed in our study work in sales teams in 299 sales districts, with each sales team operating in a single sales district. The sales force comprises two separate divisions. The sales representatives in the first division primarily acquire and sell to new customers. Their compensation is heavily commission based and depends on their sales performance (this division comprises 161 sales teams). The salespeople in the second division primarily up- and cross-sell the company's products to existing customers and service them. They receive a fixed salary (this division comprises 138 sales teams). The company does not mix sales representatives from different divisions to compose a work team; rather, they operate in separate sales teams. Sales teams of both divisions are physically distant from the firm's headquarters. The salespeople working in sales districts experience close employeecustomer interactions, a circumstance especially conducive to testing potential customer reactions to employees' headquarters stereotypes. Other industries also have these features, including insurance companies, banks and financial service providers, pharmaceutical firms, tourism companies, and retailers (e.g., clothing, computer hardware).

Data source. We acquired multiple-source data for our study. We obtained data from sales representatives nested in sales districts as well as objective firm data on the individual salesperson's sales performance. We also used customerbased data reporting how satisfied customers were with the sales interaction. We distributed questionnaires to all the company's salespeople $(n=2290)$ within 302 sales districts across the two divisions. The final sample includes 1548 sales representatives (a $67 \%$ overall response rate), of which 903 are commission based and 645 have fixed salaries, from 299 sales districts. Additional tests showed no significant differences between the responses from early versus late respondents on all the major constructs and on the key demographic variables, suggesting that nonresponse bias is not a problem in our data (Armstrong and Overton 1977).

\section{Construct Measures}

The Appendix provides a complete list of measurement items used in the study. We measured distance to headquarters as the absolute physical distance in miles between each sales team's location and the location of the corporate headquarters.

To measure salespeople's stereotypes of corporate headquarters, we followed Gardner's (1994) stereotype differential technique, which is consistent with existing work in this area (Homburg et al. 2011). We measured the organizational as well as team identification of sales representatives using Mael and Ashforth's (1992) well-established six-item scale. We measured competitive intensity with Jaworski and Kohli's (1993) four-item scale. The unit of analysis we used for this construct is the sales district (i.e., level 2), for several reasons. First, the company has no national competitor, which means that competition is on a local, or district, level. Second, talking to company representatives made it clear that the competitive intensity varies between sales districts: Salespeople who work in the same sales district compete with the same local competitors, whereas salespeople in other districts deal with different competitors. Third, data analysis shows that aggregation is necessary.

We calculated median within-group agreement (median $\mathrm{r}_{\mathrm{wg}}$ ) and intraclass correlations (ICC [1] and ICC [2]), statistics that are frequently used to justify aggregation of data to higher levels of analysis (Bliese 2000). Compared with the conventional thresholds for these statistics (James, Demaree, and Wolf 1984), the $r_{w g}$ coefficient was sufficiently high for competitive intensity $\left(\mathrm{r}_{\mathrm{wg}}=.80\right)$, as were its intraclass correlation coefficients $(\mathrm{ICC}[1]=.21, \mathrm{ICC}[2]=.52)$. These results suggested that data aggregation was appropriate. Thus, we treated competitive intensity as a group-level variable and aggregated individual representatives' ratings.

Outcomes. For sales performance, we used the yearover-year growth percentage of total sales per employee. We obtained this objective measure from the company's sales records and computed the sales trend improvement for each salesperson. We used year-over-year percentage growth in total sales per employee for two reasons. First, using trend improvements enabled us to control for seasonality, differences in sales territories and competitors, and other potential confounding factors to measure true salesperson performance (see also Ahearne et al. 2010). Second, measuring sales performance using year-over-year percentage growth of sales is an approach frequently applied in 
previous research in marketing (e.g., Lam, Kraus, and Ahearne 2010; Matsuno and Mentzer 2000).

We measured customer satisfaction with callbacks. The company's customer service department called customers within 60 minutes after a salesperson had contacted them and asked whether their request had been addressed to their complete satisfaction. These callbacks yielded a customer satisfaction measure in the form of the percentage of satisfied customers per salesperson. The response rate ranged between $90 \%$ and $100 \%$ per salesperson. These measures are the company's standard criteria for evaluating sales representatives' sales performance and customer satisfaction on a monthly basis. We used the sales performance growth and customer satisfaction for the month in which we conducted the study.

Controls. We included sales experience, job satisfaction, salespeople's control systems perception, customer orientation, organizational commitment, organizational trust, OCB, LMX, and sales representatives' corporate headquarters contact as covariates in our empirical analyses to test the robustness of the proposed relationships while controlling for important extraneous influences. We measured job satisfaction using Hackman and Oldham's (1975) wellestablished scale and organizational commitment using Allen and Meyer's (1990) scale. We evaluated customer orientation with Thomas, Soutar, and Ryan's (2001) short form of Saxe and Weitz's (1982) scale and assessed organizational trust with Doney and Cannon's scale (1997), OCB with Podsakoff and Mackenzie's (1994) well-established scale, and LMX with Graen and Uhl-Bien's (1995) scale. We measured sales representatives' perception of control systems using Oliver and Anderson's (1994) scale, which consists of 21 separate items representing five unique dimensions of the perceptions of a sales representative's control system. Following Oliver and Anderson (1994), we converted all subscales to Z-scores and additively combined them to form an index in which an outcome-based control system is represented by a lower score.

\section{Measurement Model}

We conducted an exploratory factor analysis using maximum likelihood extraction and an oblique rotation to evaluate the reflective scales. The commonalities are all greater than .54 , and the extracted (and rotated) factors account for $79.3 \%$ of the variance in the items' variance-covariance matrix. Factor loadings for all constructs ranged from .544 to .967 , with no unusually high cross-loadings. We calculated reliabilities for each scale and deemed them acceptable (all reliabilities were greater than .78; see Table 1).

In the next step, we conducted a confirmatory factor analysis. Although the chi-square statistic $(1543$, d.f. $=204)$ was significant, an examination of the comparative fit index (CFI) and standard root mean square residual (SRMR) estimates (.95 and .04 , respectively) suggests that the measurement model fits well. Furthermore, the root mean square error of approximation (RMSEA) value of .07 comes close to the recommendation of .06 or less (Hu and Bentler 1999; Kline 2005). All factor loadings of the indicators on their respective latent constructs were significant. Furthermore, the lowest composite reliability was .80 , and the lowest average variance extracted was .57 , providing evidence that all constructs possess adequate reliability and convergent validity (Bagozzi 1980; Fornell and Larcker 1981). In addition, all squared correlations between the latent constructs were smaller than the average variance extracted from the respective constructs, further supporting the measures' discriminant validity (Fornell and Larcker 1981).

\section{Analytical Approach}

Because the salespeople were nested in a particular sales district and because their data could vary across the 299 sales districts, the responses from sales representatives working in the same district might be interdependent. To determine whether a two-level approach was warranted, we examined intraclass correlation coefficients (ICC) and corresponding design effects to ascertain the extent of systematic group-level variance (Duncan et al. 1997). The resulting ICCs indicate that the proportion of total variance accounted for by between-cluster variation is of sufficient size to substantiate a multilevel approach. In addition, design effects, calculated by multiplying the ICC by (average cluster size -1 ) and adding 1 , were generally greater than 2, suggesting that a multilevel structure should not be ignored (Múthen and Satorra 1995).

Consequently, to take into account the hierarchical structure of the data, we estimated a multilevel structural equation model using MPlus 5 using full maximum likelihood (Raudenbush and Bryk 2002). This approach has the advantage over other hierarchical linear modeling methods of enabling the modeling of both structural and measurement models simultaneously. In our study, we modeled competitive intensity and distance to headquarters as level 2 variables because they vary by sales district.

\section{Results}

Because standard fit indexes are not available with the numerical integration procedure used by MPlus to estimate latent interactions, which are part of our model, we employed a log-likelihood difference test $(-2 \times$ difference in $\log$-likelihoods $\sim \chi^{2}$, d.f. $=$ number of freed paths) to compare the fit of the evaluated nested models, and we used Akaike's information criterion (AIC) and the Bayesian information criterion (BIC) to compare the fit of selected nonnested models.

We first ran an unconditional (intercepts only) model, which substantiated our multilevel design. Next, we fit a baseline model that estimated all direct effects on organizational and team identification as well as sales performance and customer satisfaction, eliminating the paths pointing to the mediating variable headquarters stereotypes while retaining headquarters stereotypes in the model. The results support the overall framework of the model.

Next, we estimated the hypothesized model. A comparison of AIC and BIC values confirms that this less restricted model fits better than the direct effects-only model (122.76 lower AIC and 128.42 lower BIC for the less restricted model). This improved model reflects significant relationships between organizational and team identification as well as competitive intensity (i.e., the antecedents) and 


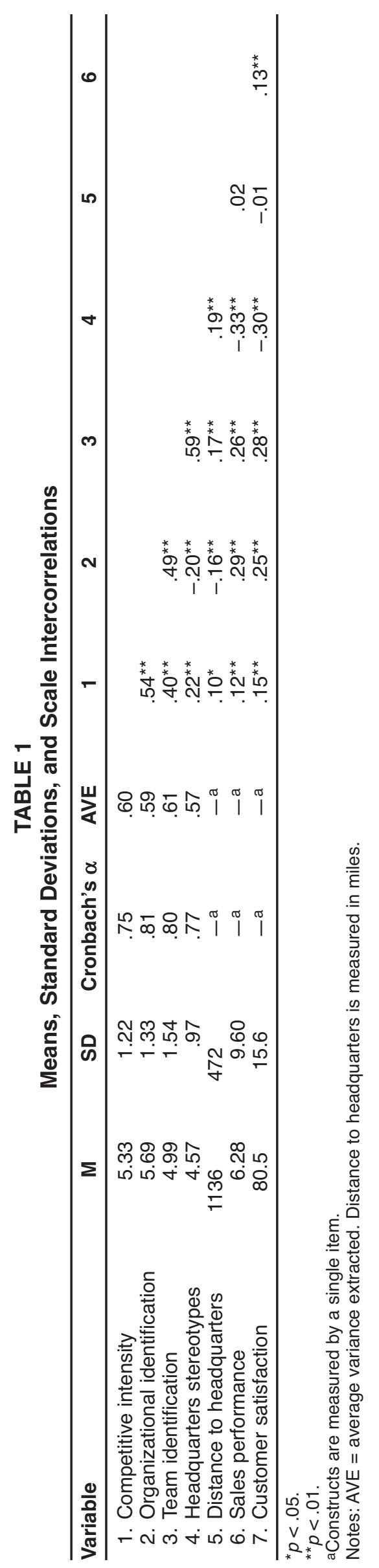


headquarters stereotypes (i.e., the mediator), fulfilling additional requirements for a mediated structure - that is, significant antecedent-final outcome and mediator-final outcome relationships (Baron and Kenny 1986).

The log-likelihood difference test for this hypothesized model confirmed that the inclusion of the effects on headquarters stereotypes provides a stronger fit to the data $\left(\Delta \chi^{2}=\right.$ 95.17 , d.f. $=7, p<.01)$ than the nested model that did not include these mediating effects. Next, we summarize model results in the context of our hypotheses.

The results indicate a negative relationship between distance to corporate headquarters and organizational identification $\left(\mathrm{H}_{1 \mathrm{a}}: \gamma=-.14, p<.05\right)$ and a positive relationship between distance to headquarters and team identification $\left(\mathrm{H}_{1 \mathrm{~b}}: \gamma=.17 p<.01\right)$, in support of $\mathrm{H}_{1 \mathrm{a}}$ and $\mathrm{H}_{1 \mathrm{~b}}$. Furthermore, we find a significant interaction between organizational and team identification as proposed in $\mathrm{H}_{2}\left(\mathrm{H}_{2}: \gamma=\right.$ $-.22, p<.01)$. As Figure 2 shows, work team identification more strongly fosters headquarters stereotypes when organizational identification is low than when it is high. A positive relationship between competitive intensity and headquarters stereotypes $(\gamma=.11, p<.05)$ substantiates $\mathrm{H}_{3}$. We also found that competitive intensity positively influences both team identification $\left(\mathrm{H}_{4 \mathrm{a}}: \gamma=.28, p<.01\right)$ and organizational identification $\left(\mathrm{H}_{4 \mathrm{~b}}: \gamma=.38, p<.01\right)$, in support of $\mathrm{H}_{4 \mathrm{a}}$ and $\mathrm{H}_{4 \mathrm{~b}}$. The significant negative impacts of headquarters stereotypes on sales performance $\left(\mathrm{H}_{5}: \gamma=-.27, p<.01\right)$ and customer satisfaction with the sales interaction $\left(\mathrm{H}_{6}: \gamma=-.23\right.$, $p<.01)$ lend support to $\mathrm{H}_{5}$ and $\mathrm{H}_{6}$, which posit that strong headquarters stereotypes will result in a decrease in sales performance as well as satisfaction with the sales interaction.

Finally, we tested whether competitive intensity moderates the relationship between distance to corporate headquarters and work team identification. We found a significant

FIGURE 2

Interaction Effect Between Team Identification
and Organizational Identification on Headquarters
Stereotypes

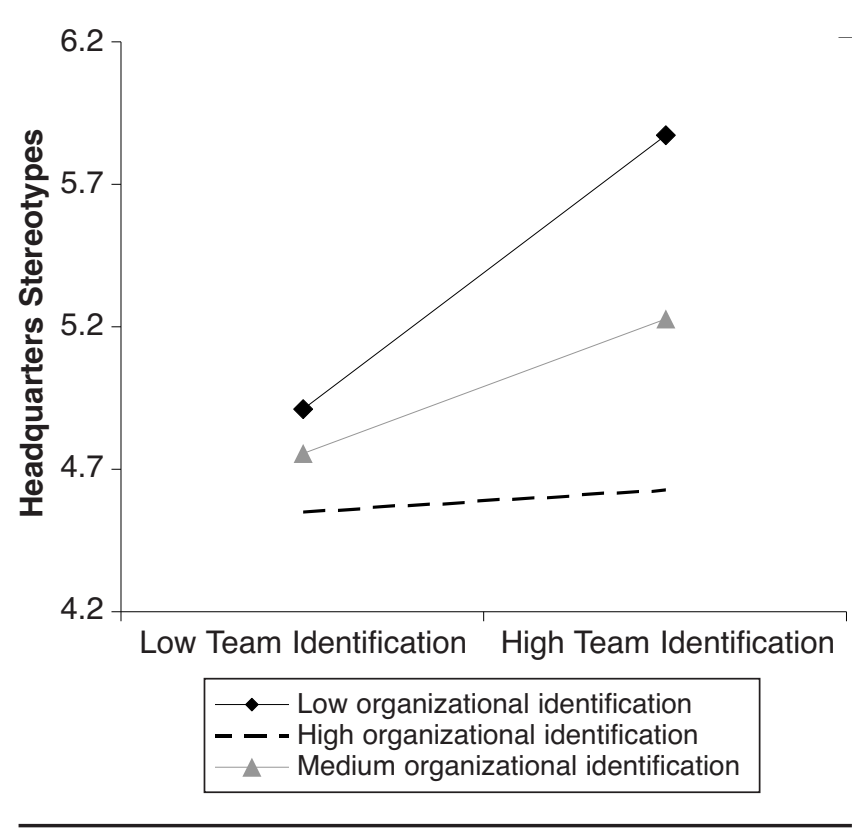

moderation effect $(\gamma=.09, p<.05)$, such that the relationship is stronger when competitive intensity is high than when it is low. ${ }^{1}$ Table 2 shows results of the series of models.

\section{Mediational Analysis}

Although the results generally support the hypothesized conceptual model, we used the comparison of log-likelihood difference tests of the baseline model and the hypothesized model to assess whether the mediations present are full or partial (Baron and Kenny 1986; MacKinnon et al. 2002; Mathieu and Taylor 2007). The hypothesized model, which included the indirect effect of organizational identification, team identification, and competitive intensity mediated through headquarters stereotypes on sales performance and customer satisfaction, exhibited a superior fit to the baseline model $\left(\Delta \chi^{2}=95.17\right.$, d.f. $\left.=7, p<.01\right)$, which did not include the effects of organizational identification, team identification, and competitive intensity on headquarters stereotypes. Although we still find significant effects of both organizational and team identification on sales performance and customer satisfaction with the sales interaction, the direct effects of competitive intensity on those outcomes lose significance when we include headquarters stereotypes as a mediator. Therefore, we find that headquarters stereotypes partially mediate the organizational and team identificationoutcomes links, while these stereotypes fully mediate the competitive intensity-outcome link.

Furthermore, in an additional analysis to rule out alternative explanations, we also tested organizational trust and OCB as mediators instead of headquarters stereotypes. Unlike headquarters stereotypes, neither trust nor OCB mediate the effects of organizational and team identification on sales performance and customer satisfaction with the sales interaction. Despite these findings, we controlled for the effects of organizational trust and OCB in the final model.

\section{Controls}

In examining the control variables, we found significant relationships between the controls and sales performance as well as customer satisfaction for most of the relationships. The results show that even in the presence of those performance predictors, sales representatives' headquarters stereotypes still decrease sales performance and customer satisfaction with the sales interaction. Moreover, our results indicate that a behavior-based control system hinders sales performance $(\gamma=-.13, p<.05)$, which means that an outcome-based control system increases sales performance. However, we also find that a behavior-based control system has a positive impact on satisfaction with the sales interaction $(\gamma=.10, p<$ $.05)$. These effects are in line with the findings from previous research. Finally, in predicting headquarters stereotypes, we controlled for LMX quality. The results indicate that LMX does not significantly influence sales representatives' headquarters stereotypes.

${ }^{1}$ Following a suggestion by an anonymous reviewer, we also tested whether sales representatives' customer orientation attenuates the negative effect of headquarters stereotypes on customer satisfaction with the sales interaction. The results support a significant moderation effect. 
TABLE 2

Model Comparison and Effects

\begin{tabular}{|c|c|c|c|c|}
\hline & $\begin{array}{c}\text { Model } 1 \\
\text { (Baseline) }\end{array}$ & $\begin{array}{c}\text { Model } 2 \\
\text { (Hypotheses) }\end{array}$ & Model 3 & Model 4 \\
\hline \multicolumn{5}{|l|}{ Relationships } \\
\hline Distance to headquarters $\rightarrow$ organizational identification $\left(\mathrm{H}_{1 \mathrm{a}}\right)$ & a) $-.16^{\star \star}$ & $-.14^{*}$ & $-.14^{\star}$ & $-.10^{\star}$ \\
\hline Distance to headquarters $\rightarrow$ team identification $\left(\mathrm{H}_{1 \mathrm{~b}}\right)$ & $.17^{\star \star}$ & $.17^{\star \star}$ & $.12^{*}$ & $.15^{\star \star}$ \\
\hline Distance to headquarters $\rightarrow$ headquarters stereotypes & $.19^{\star \star}$ & $.20^{\star \star}$ & $.16^{\star *}$ & $.14^{*}$ \\
\hline \multicolumn{5}{|l|}{ Distance to headquarters $\times$ competitive intensity $\rightarrow$} \\
\hline organizational identification & n.s. & n.s. & n.s. & n.s. \\
\hline \multicolumn{5}{|l|}{ Distance to headquarters $\times$ competitive intensity $\rightarrow$} \\
\hline \multicolumn{5}{|l|}{ Team identification $\times$ organizational identification $\rightarrow$} \\
\hline Organizational identification $\rightarrow$ headquarters stereotypes & - & $-.40^{\star \star}$ & $-.32^{\star \star}$ & $-.34^{\star *}$ \\
\hline Team identification $\rightarrow$ headquarters stereotypes & - & $.26^{\star *}$ & $.18^{\star \star}$ & $.19^{* *}$ \\
\hline Competitive intensity $\rightarrow$ headquarters stereotypes $\left(\mathrm{H}_{3}\right)$ & - & $.11^{*}$ & $.10^{*}$ & $.10^{*}$ \\
\hline Competitive intensity $\rightarrow$ team identification $\left(\mathrm{H}_{4 a}\right)$ & $.29^{\star \star}$ & $.28^{\star \star}$ & $.22^{\star \star}$ & $.21^{\star *}$ \\
\hline Competitive intensity $\rightarrow$ organizational identification $\left(\mathrm{H}_{4 \mathrm{~b}}\right)$ & $.38^{\star \star}$ & $.38^{\star \star}$ & $.31^{* *}$ & $.31^{* *}$ \\
\hline Headquarters stereotypes $\rightarrow$ sales performance $\left(\mathrm{H}_{5}\right)$ & $-.29^{\star \star}$ & $-.27^{\star \star}$ & $-.10^{\star}$ & $-.25^{\star *}$ \\
\hline Headquarters stereotypes $\rightarrow$ customer satisfaction $\left(\mathrm{H}_{6}\right)$ & $-.27^{\star \star}$ & $-.23^{\star \star}$ & $-.20^{\star \star}$ & $-.20^{\star *}$ \\
\hline Competitive intensity $\rightarrow$ sales performance & $.07^{\star}$ & n.s. & n.s. & n.s. \\
\hline Competitive intensity $\rightarrow$ customer satisfaction & $.10^{*}$ & n.s. & n.s. & n.s. \\
\hline Organizational identification $\rightarrow$ sales performance & $.17^{\star \star}$ & $.16^{\star \star}$ & $.10^{*}$ & $.10^{*}$ \\
\hline Organizational identification $\rightarrow$ customer satisfaction & $.14^{*}$ & $.13^{*}$ & $.09^{*}$ & $.10^{*}$ \\
\hline Team identification $\rightarrow$ sales performance & $.14^{\star}$ & $.11^{*}$ & $.09^{*}$ & $.09^{\star}$ \\
\hline Team identification $\rightarrow$ customer satisfaction & $.12^{*}$ & $.09^{*}$ & $.08^{*}$ & $.08^{\star}$ \\
\hline \multicolumn{5}{|l|}{ Controlled Relationships } \\
\hline Organizational identification $\rightarrow$ trust & - & $.19^{\star *}$ & $.12^{\star \star}$ & $.16^{\star \star}$ \\
\hline Team identification $\rightarrow$ trust & - & n.s. & n.s. & n.s. \\
\hline Team identification $\times$ organizational identification $\rightarrow$ trust & - & n.s. & n.s. & n.s. \\
\hline Competitive intensity $\rightarrow$ trust & - & n.s. & n.s. & n.s. \\
\hline Trust $\rightarrow$ sales performance & $.09^{*}$ & $.09^{\star}$ & $.07^{\star}$ & $.07^{\star}$ \\
\hline Trust $\rightarrow$ customer satisfaction & $.12^{*}$ & $.10^{*}$ & $.08^{*}$ & $.08^{\star}$ \\
\hline Organizational identification $\rightarrow$ OCB & - & $.21^{\star *}$ & $.13^{*}$ & $.17^{\star \star}$ \\
\hline Team identification $\rightarrow$ OCB & - & n.s. & n.s. & n.s. \\
\hline Team identification $\times$ organizational identification $\rightarrow$ OCB & - & n.s. & n.s. & n.s. \\
\hline Competitive intensity $\rightarrow$ OCB & - & n.s. & n.s. & n.s. \\
\hline $\mathrm{OCB} \rightarrow$ sales performance & $.13^{\star *}$ & $.12^{*}$ & $.08^{*}$ & $.09^{*}$ \\
\hline $\mathrm{OCB} \rightarrow$ customer satisfaction & $.15^{\star \star}$ & $.13^{\star \star}$ & $.09^{*}$ & $.10^{*}$ \\
\hline HQ contact $\rightarrow$ headquarters stereotypes & - & n.s. & n.s. & n.s. \\
\hline LMX $\rightarrow$ headquarters stereotypes & - & n.s. & n.s. & n.s. \\
\hline Sales experience $\rightarrow$ sales performance & $.09^{*}$ & $.08^{*}$ & $.07^{*}$ & $.08^{\star}$ \\
\hline Job satisfaction $\rightarrow$ sales performance & n.s. & n.s. & n.s. & n.s. \\
\hline Control systems $\rightarrow$ sales performance & $-.15^{\star \star}$ & $-.13^{\star}$ & $-.11^{*}$ & $-.10^{\star}$ \\
\hline Organizational commitment $\rightarrow$ sales performance & $.16^{\star \star}$ & $.13^{\star \star}$ & $.13^{\star \star}$ & $.15^{\star \star}$ \\
\hline Customer orientation $\rightarrow$ sales performance & $.20^{* *}$ & $.18^{* *}$ & $.18^{\star *}$ & $.16^{\star *}$ \\
\hline Sales experience $\rightarrow$ customer satisfaction & $.12^{\star}$ & $.10^{*}$ & $.08^{*}$ & $.10^{*}$ \\
\hline Job satisfaction $\rightarrow$ customer satisfaction & n.s. & n.s. & n.s. & n.s. \\
\hline Control systems $\rightarrow$ customer satisfaction & $.11^{*}$ & $.10^{*}$ & $.09^{\star}$ & $.10^{\star}$ \\
\hline Organizational commitment $\rightarrow$ customer satisfaction & n.s. & n.s. & n.s. & n.s. \\
\hline Customer orientation $\rightarrow$ customer satisfaction & $.21^{\star \star}$ & $19^{\star *}$ & $.19^{\star \star}$ & $.18^{\star *}$ \\
\hline d.f. & 237 & 223 & 447 & 447 \\
\hline $\begin{array}{l}\text { Log-likelihood } \\
\qquad(-2 L L \text { change) }\end{array}$ & $\begin{array}{r}4,018.43 \\
(-)\end{array}$ & $\begin{array}{c}-23,922.98 \\
\left(95.45^{\star \star}\right)\end{array}$ & $\begin{array}{r}-27,848.17 \\
(-)\end{array}$ & $\begin{array}{r}-27,848.17 \\
(-)\end{array}$ \\
\hline AIC & $2,184.67$ & $52,061.04$ & $52,672.12$ & $52,672.12$ \\
\hline $\mathrm{BIC}$ & $2,815.43$ & $52,686.30$ & $53,431.23$ & $53,431.23$ \\
\hline
\end{tabular}

${ }^{*} p<.05$.

${ }^{\star *} p<.01$

Notes: n.s. = not significant. Model 3: Commission-based sales representatives only; Model 4: Fixed salary-based sales representatives only. 


\section{Additional Analysis}

Because the sales representatives' compensation (commissions vs. fixed salary) differs across the two divisions, we ran our model using the data from the commission-based sales representatives and the salespeople with fixed salaries separately to examine whether the results change. We conducted a multigroup analysis using the affiliation with the division as grouping variable. ${ }^{2}$ The last two columns of Table 2 summarize of our findings. The results for the two divisions are virtually identical, with no differences in the significance of relationships among the variables of interest. However, a significant finding is that the impact of headquarters stereotypes on sales performance is much less negative for the sales representatives whose salaries are heavily commission based $(\gamma=-.10, p<.05)$ than for the sales representatives with fixed salaries $(\gamma=-.25, p<.01)$. In contrast, the negative effects on customer satisfaction with the sales interaction are the same for the commissionbased $(\gamma=-.20, p<.01)$ and fixed salary $(\gamma=-.20, p<.01)$ sales representatives.

To test for the significance of this difference, we compared the chi-square from a model with all parameters allowed to be unequal across groups to the chi-square from a model with only the effect of interest-sales performance regressed on headquarters stereotypes, constrained to be equal across groups. The model with all parameters freely estimated in the two groups reached acceptable fit measures $(\mathrm{CFI}=.92, \mathrm{RMSEA}=.06, \mathrm{SRMR}=.04)$. Although the CFI is slightly below the value $\mathrm{Hu}$ and Bentler (1999) suggest, in combination with an RMSEA of .06 and an SRMR of .04 , the model fit is acceptable.

The partial invariance model with the effect of interest constrained to be equal across commission- and salarybased sales representatives showed a significantly poorer model fit $\left(\Delta \chi^{2}(1)=13.67, p<.01\right)$. The CFI of .87 , the SRMR of .132, and the RMSEA of .163 suggest that the fit can be improved. The findings imply that the size of the negative coefficient for the headquarters stereotypes-sales performance link differs significantly across the two divisions. In summary, the impact of headquarters stereotypes on sales performance is significantly less negative for sales representatives who are heavily compensated on commission than for those who receive a fixed salary. At the same time, the negative effects on customer satisfaction are virtually identical for both groups.

\section{General Discussion}

Drawing on the notion of multiple nested identities and the social identity approach (Tajfel and Turner 1986), we proposed and empirically tested our hypotheses. The results show that physical distance from the corporate headquarters enhances sales representatives' work team identification and diminishes their organizational identification. Identifi-

\footnotetext{
${ }^{2} \mathrm{We}$ also evaluated the invariance of the measurement model across the two groups of sales representatives. The factor structure is invariant across groups, providing evidence that the derived scales can be used with some confidence in both groups of sales representative.
}

cation with the work team most strongly contributes to the prevalence of negative headquarters stereotypes when organizational identification is low, and headquarters stereotypes in turn lower sales performance and customer satisfaction with the sales interaction. Competitive intensity increases social identification at both levels and also directly triggers headquarters stereotypes. Furthermore, different compensation systems (commission based vs. fixed salary) do not forestall the negative effects of headquarters stereotypes on sales performance and customer satisfaction with the sales interaction.

\section{Limitations and Theoretical Implications}

The collection of a large-scale, multilevel data set, such as the one on which our study is based, was only possible by working closely with one company. Although this company is structurally characteristic for its industry (e.g., insurance companies, banks and financial service providers, tourism companies, retailers), further research is needed to examine the cross-industry stability of our findings. Furthermore, in our study, we merely considered negative stereotypes. However, according to the social psychology literature, positive and mixed group stereotypes can exist as well. For example, stereotypes against elderly people might include positive (e.g., wise) and negative (e.g., senile) traits. Therefore, further research should investigate the role of positive stereotypes in marketing and management.

The current study makes important contributions to the field of applied social identity theory in marketing and sales management research (e.g., Bhattacharya and Sen 2003; Homburg, Wieseke, and Hoyer 2009; Hughes and Ahearne 2010). Whereas prior research has concentrated merely on positive outcomes of social identification in organizations (e.g., OCB, organizational commitment, increased performance), this study investigates the link between social identification in organizations and the prevalence of intraorganizational stereotyping as a negative outcome of identification. Therefore, linking the concept of stereotypes to social identification, we challenge the notion that social identification is thoroughly desirable, which has been asserted in previous marketing research. Given that applications of the social identity approach and social identification are still gaining momentum in marketing and given our results, which show that headquarters stereotypes can adversely influence both sales performance and customer satisfaction with the sales interaction, stereotypes are highly relevant for further research.

Moreover, the concept of stereotypes matters because of its theoretical connection with intergroup-related topics in the marketing and sales literature. For example, stereotypes can serve as a fruitful basis for explaining the interface between marketing and other business functions, such as marketing's boundaries with sales or research and development. This stream of research lacks a thorough theoretical foundation. Thus, the construct of stereotypes, with its strong theoretical background, could enrich the marketing interface literature.

Another important contribution of our study lies in the simultaneous examination of sales representatives' multiple 
nested identifications. Our results show that identification with higher- and lower-order identities together shape how sales representatives interpret intergroup contexts in organizations. Prior work in marketing has focused exclusively on higher-order foci, such as organizational identification (e.g., Homburg, Wieseke, and Hoyer 2009; Wieseke et al. 2009). Therefore, to provide a more complete understanding of members' identity construction in organizations, further research should acknowledge that identities are complex, multifaceted, and most often nested rather than simplistic and dichotomous.

Furthermore, we advance research on social identity threats, which is still in its infancy. As our results indicate, a threat to a social identity in the form of perceived competitive intensity can foster intergroup stereotyping. Identity threats can also arise from inside the organizationfor example, in the form of a struggle for scarce resources between different organizational subgroups such as departments or work teams. Therefore, the logic of uncertainty reduction and self-enhancement could also contribute to a better understanding of the dynamics between marketing and other thought worlds within organizations (Homburg and Jensen 2007).

The present study offers a promising beginning point for more thorough investigations of how stereotypes develop and persist in organizations. If organizations are "storytelling systems" (Ashforth, Harrison, and Corley 2008; Cradador and Pratt 2006), organizational narratives that are commonly shared by work teams might be a way of communicating intergroup stereotypes. Therefore, another avenue for further research might be to examine how stereotypes are transmitted between members of a work team and how organizational narratives are involved in this transmission process. This pattern of relationships might also be fruitful from the perspective of newcomers' organizational socialization.

\section{Managerial Implications}

Complementing the previously mentioned theoretical implications, the current study also holds crucial insights for managers. Because meta-analytic evidence suggests that identification with organizational subgroups tends to be more salient than identification with organizations (Riketta and Van Dick 2005), a key implication for management practice is that stereotypes and their negative performance outcomes are prevalent in many organizations. Thus, managers should take stereotypes very seriously, especially with respect to employees working in geographically dispersed teams, far from their corporate headquarters. Such conditions promote identification with lower-order identities, which can result in fierce subgroup loyalty and, ultimately, intergroup stereotyping. A high degree of work team identification may be particularly detrimental if it is associated with a low degree of organizational identification. Therefore, managers should try to enhance organizational identification in geographically dispersed teams and should not rely exclusively on sales representatives' work team identification, as conventional managerial wisdom may suggest. Organizational identification can be achieved best with organization-level procedures, such as giving sales representatives the chance to voice their opinion on important organizational matters (Olkkonen and Lipponen 2006). Furthermore, according to the structural perspective on social identities (Dutton, Roberts, and Bednar 2010), to minimize intergroup stereotyping, managers should balance inclusive and exclusive organizational identity domains. That is, the organizational identity should provide a common frame of reference, balancing people's needs for inclusiveness and distinctiveness (Brewer 1991).

Underscoring the importance of this managerial action is the finding that negative effects of intergroup stereotyping are not ameliorated different compensation systems (commission based vs. fixed salary). Although the impact of headquarters stereotypes on sales performance is much less negative under commission-based conditions than under fixed-salary conditions, it remains significantly negative. Furthermore, the negative effects on customer satisfaction are the same for both compensation systems. However, although the prevalence of intergroup stereotypes in organizations might to some extent be inevitable, managers can try to foster their sales representatives' customer orientation to attenuate the negative impact of stereotypes on customer satisfaction with the sales interaction.

As our results show, intense competition fosters identification with the organization as a whole and with salespeople's work teams. However, managers should use caution in relying on such external identification triggers, because a high level of work team identification leads to increased prevalence of intergroup stereotyping. This consideration is particularly critical, because managers can influence the perceived level of competitive intensity by providing competitive information to their sales representatives.

\section{Appendix Measurement Scales}

\section{Stereotypes}

Gardner (1994); Homburg et al. (2011) (seven-point semantic differential scale)

1. The people in corporate headquarters know what is really involved with selling [organization's name] products... (1) "very well" (7) "not at all."

2 . The people in corporate headquarters are primarily concerned with... (1) "the interest of the salespeople" (7) "their own interest."

3. The people in the corporate headquarters get paid...(1) "too little" (7) "too much."

4. Compared to the sales force, people in corporate headquarters work...(1) "less" (7) "more."

5. Compared to here, the working conditions in corporate headquarters are...(1) "less pleasant" (7) "more pleasant."

6. Our corporate headquarters...(1) "is worth more than it costs" (7) "costs more than it is worth."

\section{Organizational Identification}

Mael and Ashforth (1992) (1 = "strongly disagree," and 7 = "strongly agree") 
1. When someone criticizes [organization's name], it feels like a personal insult.

2. I am very interested in what others think about [organization's name].

3. When I talk about [organization's name], I usually say "we" rather than "they."

4. This organization's successes are my successes.

5. When someone praises this organization, it feels like a personal compliment.

6. If a story in the media criticized [organization's name], I would feel embarrassed.

\section{Team Identification}

Mael and Ashforth (1992) (1 = "strongly disagree," and $7=$ "strongly agree")

1. When someone criticizes the colleagues in my sales district, it feels like a personal insult.
2. I am very interested in what others think about the colleagues in my sales district.

3. When I talk about the colleagues in my sales district, I usually say "we" rather than "they."

4. My colleagues' successes are my successes.

5. When someone praises the colleagues in my sales district, it feels like a personal compliment.

6. If a story in the media criticized the colleagues in my sales district, I would feel embarrassed.

\section{Competitive Intensity}

Adapted from Jaworski and Kohli (1993) (1 = "strongly disagree," and 7 = "strongly agree")

1. Competition in my district is cutthroat.

2. Competitors in my district are relatively strong.

3. In my district, the competition with suppliers offering products and services similar to [organization's name]'s is immense.

\section{REFERENCES}

Ahearne, Michael, C.B. Bhattacharya, and Thomas Gruen (2005), "Antecedents and Consequences of Customer-Company Identification: Expanding the Role of Relationship Marketing," Journal of Applied Psychology, 90 (3), 574-85.

_ Son K. Lam, John E. Mathieu, and Willy Bolander (2010), "Why Are Some Salespeople Better at Adapting to Organizational Change?" Journal of Marketing, 74 (May), 65-79.

- Narasimhan Srinivasan, and Luke Weinstein (2008), "Effect of Technology on Sales Performance: Progressing from Technology Acceptance to Technology Usage and Consequence," Journal of Personal Selling and Sales Management, 24 (4), 297-310.

Albert, Stuart, Blake E. Ashforth, and Janet E. Dutton (2000), "Organizational Identity and Identification: Charting New Waters and Building New Bridges," Academy of Management Review, 25 (1), 13-17.

Allen, Natalie J. and John P. Meyer (1990), “The Measurement and Antecedents of Affective, Continuance, and Normative Commitment to the Organization," Journal of Occupational Psychology, 63 (1), 1-18.

Alvesson, Mats and Hugh Willmott (2002), "Identity Regulation as Organizational Control: Producing the Appropriate Individual," Journal of Management Studies, 39 (5), 619-44.

Anderson, Erin and Richard L. Oliver (1987), "Perspectives on Behavior Based Versus Outcome-Based Salesforce Control Systems," Journal of Marketing, 51 (October), 76-88.

Armstrong, Scott J. and Terry S. Overton (1977), "Estimating Nonresponse Bias in Mail Surveys," Journal of Marketing Research, 14 (August), 396-402.

Ashforth, Blake E., Spencer H. Harrison, and Kevin G. Corley (2008), "Identification in Organizations: An Examination of Four Fundamental Questions," Journal of Management, 34 (3), 325-74.

_ and Scott A. Johnson (2001), "Which Hat to Wear? The Relative Salience of Multiple Identities in Organizational Contexts," in Social Identity Processes in Organizational Contexts, M.A. Hogg and D.J. Terry, eds. Philadelphia: Psychology Press, 31-48.

_ and Fred Mael (1989), "Social Identity Theory and the Organization," Academy of Management Review, 14 (1), 20-39. — and - (1998), "The Power of Resistance: Sustaining Valued Identities," in Power and Influence in Organizations, Roderick M. Kramer and Margaret A. Neale, eds. Thousand Oaks, CA: Sage Publications, 89-119.
Bagozzi, Richard P. (1980), Causal Models in Marketing. New York: John Wiley \& Sons.

Bargh, John A., Mark Chen, and Lara Burrows (1996), "Automaticity of Social Behavior: Direct Effects of Trait Construct and Stereotype Activation on Action," Journal of Personality and Social Psychology, 71 (2), 230-44.

Baron, Reuben M. and David A. Kenny (1986), "The ModeratorMediator Variable Distinction in Social Psychological Research: Conceptual, Strategic, and Statistical Considerations," Journal of Personality and Social Psychology, 51 (6), 1173-82.

Barsade, Sigal G. (2002), "The Ripple Effect: Emotional Contagion and Its Influence on Group Behavior," Administrative Science Quarterly, 47 (4), 644-75.

Bartel, Caroline A. (2001), "Social Comparisons in BoundarySpanning Work: Effects of Community Outreach on Members' Organizational Identity and Identification," Administrative Science Quarterly, 46 (3), 379-413.

Bartels, Jos, Ad Pruyn, Menno De Jong, and Inge Joustra (2007), "Multiple Organizational Identification Levels and the Impact of Perceived External Prestige and Communication Climate," Journal of Organizational Behavior, 28 (2), 173-90.

Bhattacharya, C.B. and Sankar Sen (2003), "Consumer-Company Identification: A Framework for Understanding Consumers' Relationships with Companies," Journal of Marketing, 76 (April), 76-88.

Bitner, Mary Jo, Bernard H. Booms, and Lois A. Mohr (1994), "Critical Service Encounters: The Employee's Viewpoint," Journal of Marketing, 58 (October), 95-106.

Bliese, Paul (2000), "Within-Group Agreement, Non-Independence, and Reliability," in Multilevel Theory, Research, and Methods in Organization, K. Klein and S. Kozlowski, eds. San Francisco: Jossey-Bass, 349-81.

Branscombe, Nyla R. and Daniel L. Wann (1994), "Collective Self-Esteem Consequences of Outgroup Derogation When a Valued Social Identity Is on Trial," European Journal of Social Psychology, 24 (7), 641-57.

Brewer, Marilynn B. (1991), "The Social Self: On Being the Same and Different at the Same Time," Personality and Social Psychology Bulletin, 17 (5), 475-82.

Brown, Rupert and Miles Hewstone (2005), "An Integrative Theory of Intergroup Contact," in Advances in Experimental Social Psychology, M. Zanna, ed. San Diego: Academic Press, 255-343. 
Brown, Steven and Robert A. Peterson (1994), "The Effect of Effort on Sales Performance and Job Satisfaction," Journal of Marketing, 58 (April), 70-80.

Caprariello, Peter A., Amy J.C. Cuddy, and Susan T. Fiske (2009), "Social Structure Shapes Cultural Stereotypes and Emotions: A Causal Test of the Stereotype Content Model," Group Processes and Intergroup Relations, 12 (2), 147-55.

Celsi, Mary and Mary C. Gilly (2010), "Employees as Internal Audience: How Advertising Affects Employees' Customer Focus," Journal of the Academy of Marketing Science, 38 (4), 520-29.

Chandrashekaran, Murali, Kevin McNeilly, Frederick A. Russ, and Detelina Marinova (2000), "From Uncertain Intentions to Actual Behavior: A Threshold Model of Whether and When Salespeople Quit," Journal of Marketing Research, 37 (October), 463-79.

Chattopadhyay, Prithviraj, William H. Glick, and George P. Huber (2001), "Organizational Actions in Response to Threats and Opportunities," Academy of Management Journal, 44 (5), 937-55.

Christen, Markus, Ganesh Iyer, and David Soberman (2006), “Job Satisfaction, Job Performance, and Effort: A Reexamination Using Agency Theory," Journal of Marketing, 70 (January), 137-50.

Correll, Joshua, Bernadette Park, Bernd Wittenbrink, and Charles M. Judd (2002), "The Police Officer's Dilemma: Using Ethnicity to Disambiguate Potentially Threatening Individuals," Journal of Personality and Social Psychology, 83 (6), 1314-29.

Cradador, Teresa M. and Michael G. Pratt (2006), "Identification Management and Its Bases: Bridging Management and Marketing Perspectives Through a Focus on Affiliation Dimensions," Journal of the Academy of Marketing Science, 34 (2), 174-84.

Crisp, Richard J. and Miles Hewstone (2000), "Crossed Categorization and Intergroup Bias: The Moderating Roles of Intergroup and Affective Context," Journal of Experimental Social Psychology, 36 (5), 357-83.

Cuddy, Amy J.C., Susan T. Fiske, and Peter Glick (2007), "The BIAS Map: Behaviors from Intergroup Affect and Stereotypes," Journal of Personality and Social Psychology, 92 (4), 631-48.

Devine, Patricia G. (1989), "Stereotypes and Prejudice: Their Automatic and Controlled Components," Journal of Personality and Social Psychology, 56 (1), 5-18.

DiSanza, James R. and Connie Bullis (1999), "Everybody Identifies with Smokey the Bear: Employee Responses to Newsletter Identification Inducements at the U.S. Forest Service," Management Communication Quarterly, 12 (3), 347-99.

Doney, Patricia M. and Joseph P. Cannon (1997), "An Examination of the Nature of Trust in Buyer-Seller Relationships," Journal of Marketing, 61 (April), 35-51.

Doosje, Bertjan, Naomi Ellemers, and Russell Spears (1995), "Perceived Intragroup Variability as a Function of Group Status and Identification," Journal of Experimental Social Psychology, 31 (5), 410-36.

Dukerich, Janet M., Brian R. Golden, and Stephen M. Shortell (2002), "Beauty Is in the Eye of the Beholder: The Impact of Organizational Identification, Identity, and Image on the Cooperative Behaviours of Physicians," Administrative Science Quarterly, 47 (3), 507-533.

Duncan, Terry E., Susan C. Duncan, Anthony Alpert, Hyman Hops, Mike Stoolmiller, and Bengt Múthen (1997), "Latent Variable Modeling of Longitudinal and Multilevel Substance Use Data," Multivariate Behavioral Research, 32 (3), 275-318.

Dutton, Jane E. and Susan E. Jackson (1987), "Categorizing Strategic Issues: Links to Organizational Action," Academy of Management Review, 12 (1), 366-80.
— Laura M. Roberts, and Jeffrey Bednar (2010), "Pathways for Positive Identity Construction at Work: Four Types of Positive Identity and the Building of Social Resources," Academy of Management Review, 35 (2), 265-93.

Edwards, Martin R. (2005), "Organizational Identification: A Conceptual and Operational Review," International Journal of Management Reviews, 7 (4), 207-230.

Ellemers, Naomi (1993), "The Influence of Socio-Structural Variables on Identity Enhancement Strategies," European Review of Social Psychology, 4 (1), 27-57.

- and Arjan E.R. Bos (1998), "Social Identity, Relative Deprivation, and Coping with the Threat of Position Loss: A Field Study Among Native Shopkeepers in Amsterdam," Journal of Applied Social Psychology, 28 (21), 1987-2006.

—, Dick de Gilder, and Alexander S. Haslam (2004), "Motivating Individuals and Groups at Work: A Social Identity Perspective on Leadership and Group Performance," Academy of Management Review, 29 (3), 459-78.

Elsbach, Kimberly D. and Roderick M. Kramer (1996), "Members` Responses to Organizational Identity Threats: Encountering and Countering the Business Week Rankings," Administrative Science Quarterly, 41 (3), 442-76.

Fein, Steven and Steven Spencer (1997), "Prejudice as Self-Image Maintenance: Affirming the Self Through Derogating Others," Journal of Personality and Social Psychology, 73 (1), 31-44.

Fisher, Robert J., Elliot Maltz, and Bernard J. Jaworski (1997), "Enhancing Communication Between Marketing and Engineering: The Moderating Role of Relative Functional Identification," Journal of Marketing, 61 (July), 54-70.

Fiske, Susan T., Amy Cuddy, and Peter Glick (2007), "Universal Dimensions of Social Cognition: Warmth and Competence," Trends in Cognitive Sciences, 11 (2), 77-83.

Fornell, Claes and David F. Larcker (1981), "Evaluating Structural Equation Models with Unobservable Variables and Measurement Error," Journal of Marketing Research, 18 (February), 39-50.

Franke, George R. and Jeong-Eun Park (2006), "Salesperson Adaptive Selling Behavior and Customer Orientation," Journal of Marketing Research, 43 (November), 693-702.

Fujita, Kentaro, Marlone D. Henderson, Juliana Eng, Yaacov Trope, and Nira Liberman (2006), "Spatial Distance and Mental Construal of Social Events," Psychological Science, 17 (4), 278-82.

Gardner, Robert C. (1994), "Stereotypes as Consensual Beliefs," in The Psychology of Prejudice, Mark P. Zanna, and James M. Olson, eds. Hillsdale, NJ: Lawrence Erlbaum Associates, 1-33.

Graen, George B. and Mary Uhl-Bien, (1995), "RelationshipBased Approach to Leadership: Development of Leader-Member Exchange (LMX) Theory of Leadership over 25 Years: Applying a Multi-Level Multi-Domain Perspective," The Leadership Quarterly, 6 (2), 219-47.

Grieve, Paul G. and Michael A. Hogg (1999), "Subjective Uncertainty and Intergroup Discrimination in the Minimal Group Situation," Personality and Social Psychology Bulletin, 25 (8), 926-40.

Gustafsson, Anders, Michael D. Johnson, and Inger Ross (2005), "The Effects of Customer Satisfaction, Relationship Commitment Dimensions, and Triggers on Customer Retention," Journal of Marketing, 69 (October), 210-18.

Hackman, J. Richard and Greg R. Oldham (1975), "Development of the Job Diagnostic Survey," Journal of Applied Psychology, $60(2), 159-70$

Hamilton, David L. and Robert K. Gifford (1976), "Illusory Correlation in Interpersonal Perception: A Cognitive Basis of Stereotypic Judgments," Journal of Experimental Social Psychology, 12 (4), 392-407.

Harasty, Amy S. (1997), "The Interpersonal Nature of Social Stereotypes: Differential Discussion Patterns About In-Groups and Out-Groups," Personality and Social Psychology Bulletin, $23(3), 270-84$. 
Hartline, Michael D., James G. Maxham, and Daryl O. McKee (2000), "Corridors of Influence in the Dissemination of CustomerOriented Strategy to Customer Contact Service Employees," Journal of Marketing, 64 (April), 35-50.

Haslam, S. Alexander (2001), Psychology in Organizations: The Social Identity Approach. London: Sage Publications.

_ and Naomi Ellemers (2005), "Social Identity in Industrial and Organizational Psychology: Concepts, Controversies and Contributions," International Review of Industrial and Organizational Psychology, Vol. 20, G.P. Hodgkinson and J.K. Ford, eds. Chichester, UK: John Wiley \& Sons, 39-118.

- and John C. Turner (1992), "Context-Dependent Variation in Social Stereotyping 2: The Relationship Between Frame of Reference, Self-Categorization and Accentuation," European Journal of Social Psychology, 22 (3), 251-77.

Heilman, Madeline E. and Tyler G. Okimoto (2008), "Motherhood: A Potential Source of Bias in Employment Decisions," Journal of Applied Psychology, 93 (1), 189-98.

Hekman, David R., Gregory A. Bigley, H. Kevin Steensma, and James F. Hereford (2009) "Combined Effects of Organizational and Professional Identification on the Reciprocity Dynamic for Professional Employees," Academy of Management Journal, 52 (3), 506-526.

Henderson, Marlone D. (2009), "Psychological Distance and Group Judgments: The Effect of Physical Distance on Beliefs About Common Goals," Personality and Social Psychology Bulletin, 35 (10), 1330-41.

Hennig-Thurau, Thorsten, Markus Groth, Michael Paul, and Dwayne D. Gremler (2006), “Are All Smiles Created Equal? How Emotional Contagion and Emotional Labor Affect Service Relationships," Journal of Marketing, 70 (July), 58-73.

Hewstone, Miles, Mir R. Islam, and Charles M. Judd (1993), "Models of Crossed Categorization and Intergroup Relations," Journal of Personality and Social Psychology, 64 (5), 779-93.

—_, Robin Martin, Claudia Hammer-Hewstone, Richard J. Crisp, and Alberto Voci (2001), "Majority-Minority Relations in Organizations; Challenges and Opportunities," in Social Identity Processes in Organizational Contexts, M.A Hogg and D.J. Terry, eds. Philadelphia: Psychology Press, 68-86.

— , Mark Rubin, and Hazel Willis (2002), "Intergroup Bias," Annual Review of Psychology, 53 (1), 575-604.

Hilton, James L. and William von Hippel (1996), "Stereotypes," Annual Review of Psychology, 47 (1), 237-71.

Hogg, Michael A. (2000), "Subjective Uncertainty Reduction Through Self-Categorization: A Motivational Theory of Social Identity Processes," European Review of Social Psychology, 11 (1), 223-55.

- (2008), "Personality, Individuality, and Social Identity," in Personality and Social Behavior, F. Rhodewalt, ed. New York: Psychology Press, 177-96.

— and Dominic Abrams (1988), Social Identifications: A Social Psychology of Intergroup Relations and Group Processes. London: Routledge.

—_ David K. Sherman, Joel Dierselhuis, Angela T. Maitner, and Graham Moffitt (2007), "Uncertainty, Entitativity, and Group Identification," Journal of Experimental Social Psychology, 43 (1), 135-42.

Homburg, Christian and Ove Jensen (2007), "The Thought Worlds of Marketing and Sales: Which Differences Make a Difference?" Journal of Marketing 71 (July), 124-42.

— Jan Wieseke, and Wayne D. Hoyer (2009), "Social Identity and the Service-Profit Chain," Journal of Marketing, 73 (April), 38-54.

—_ B Bryan A. Lukas, and Sven Mikolon (2011), "When Salespeople Develop Negative Headquarters Stereotypes: Performance Effects and Managerial Remedies," Journal of the Academy of Marketing Science, 39 (5), 664-82.
$\mathrm{Hu}, \mathrm{Li}-\mathrm{Tze}$ and Peter M. Bentler (1999), "Fit Indices in Covariance Structure Modeling: Sensitivity to Underparameterized Model Misspecification," Psychological Methods, 3 (4), 424-53.

Hughes, Douglas E. and Michael Ahearne (2010), "Energizing the Reseller's Sales Force: The Power of Brand Identification," Journal of Marketing, 74 (October), 81-96.

Huo, Yuen J., Heather J. Smith, Tom R. Tyler, and E. Allan Lind (1996), "Superordinate Identification, Subgroup Identification, and Justice Concerns: Is Separatism the Problem; Is Assimilation the Answer?" Psychological Science, 7 (1), 40-45.

James, Lawrence R., Robert G. Demaree, and Gerrit Wolf (1984), "Estimating Within-Group Inter-Rater Reliability with and Without Response Bias," Journal of Applied Psychology, 69 (1), 85-98.

Jaworski, Bernard and Ajay K. Kohli (1993), "Market Orientation: Antecedents and Consequences," Journal of Marketing, 57 (April), 53-70.

Johnson, Michael D., Frederick P. Morgeson, Daniel R. Ilgen, Christopher J. Meyer, and James W. Lloyd (2006), "Multiple Professional Identities: Differences in Identification Across Work-Related Targets," Journal of Applied Psychology, 91 (2), 498-506.

Jones, Eli, Suresh Sundaram, and Wynne Chin (2002), "Factors Leading to Sales Force Automation Use: A Longitudinal Analysis," Journal of Personal Selling and Sales Management, $22(3), 145-56$.

Keaveney, Susan M. (1995), "Customer Switching Behavior in Service Industries: An Exploratory Study," Journal of Marketing, 59 (April), 71-82.

Kline, Rex B. (2005), Principles and Practice of Structural Equation Modeling. New York: The Guilford Press.

Kramer, Roderick M. (1993), "Cooperation and Organizational Identification," in Social Psychology in Organizations, J.K. Murnigham, ed. Englewood Cliffs, NJ: Prentice Hall, 244-69.

Krueger, Joachim I., Julie H. Hall, Paola Villano, and Meredith C. Jones (2008), "Attribution and Categorization Effects in the Representation of Gender Stereotypes," Group Processes and Intergroup Relations, 11 (3), 401-414.

Lam, Son K., Florian Kraus, and Michael Ahearne (2010), "The Diffusion of Market Orientation Throughout the Organization: A Social Learning Theory Perspective," Journal of Marketing, 74 (September), 61-79.

Larson, Brian, Karen E. Flaherty, Alex R. Zablax, Tom J. Brown, and Josuha L. Wiener (2008), "Linking Cause-Related Marketing to Sales-Force Responses and Performance in a Direct Selling Context," Journal of the Academy of Marketing Science, 36 (2), 271-77.

Leach, Colin W., Russell Spears, Nyla R. Branscombe, and Bertjan Doosje (2003), "Malicious Pleasure: Schadenfreude at the Suffering of Another Group," Journal of Personality and Social Psychology, 84 (5), 932-43.

Liao, Hui and Aichia Chuang (2004), "A Multilevel Investigation of Factors Influencing Employee Service Performance and Customer Outcomes," Academy of Management Journal, 47 (1), 41-58.

MacKenzie, Scott B., Philip M. Podsakoff, and Michael Ahearne (1998), "Some Possible Antecedents and Consequences of InRole and Extra-Role Salesperson Performance," Journal of Marketing, 62 (July), 87-98.

MacKinnon, David P., Chondra M. Lockwood, Jeanne M. Hoffmann, Stephen G. West, and Virgil Sheets (2002), “A Comparison of Methods to Test Mediation and Other Intervening Variable Effects," Psychological Methods, 7 (1), 83-104.

Macrae, C. Neil and Galen V. Bodenhausen (2000), "Social Cognition: Thinking Categorically About Others," Annual Review of Psychology, 51, 93-120. 
Mael, Fred A. and Blake Ashforth (1992), "Alumni and Their Alma Mater: A Partial Test of the Reformulated Model of Organizational Identification," Journal of Organizational Behavior, 13 (2), 103-123.

Mathieu, John E. and Scott R. Taylor (2007), “A Framework for Testing Meso-Meditational Relationships in Organizational Behavior," Journal of Organizational Behavior, 28 (2), 141-72.

Matsuno, Ken and John T. Mentzer (2000), "The Effects of Strategy Type on the Market Orientation-Performance Relationship," Journal of Marketing, 64 (October), 1-16.

McGregor, Ian and Denise C. Marigold (2003), "Defensive Zeal and the Uncertain Self: What Makes You So Sure?" Journal of Personality and Social Psychology, 85 (5), 838-52.

—_, Mark Zanna, John Holmes, and John Spencer (2001), "Compensatory Conviction in the Face of Personal Uncertainty: Going to Extremes and Being Oneself," Journal of Personality and Social Psychology, 80 (3), 472-88.

Meyer, John P., Thomas E. Becker, and Rolf van Dick (2006), "Social Identities and Commitments at Work: Toward an Integrative Model," Journal of Organizational Behavior, 27 (5), 665-83.

Monteith, Margo J., Patricia G. Devine, and Julia R. Zuwerink (1993), "Self-Directed Versus Other-Directed Affect as a Consequence of Prejudice-Related Discrepancies," Journal of Personality and Social Psychology, 68 (2), 198-210.

Múthen, Bengt and Albert Satorra (1995), "Complex Sample Data in Structural Equation Modeling," Sociological Methodology, 25, 267-316.

Oliver, Richard L. (1980), "A Cognitive Model of the Antecedents and Consequences of Satisfaction Decisions," Journal of Marketing Research, 17 (October), 460-69.

— and Erin Anderson (1994), "An Empirical Test of the Consequences of Behavior- and Outcome-Based Sales Control Systems," Journal of Marketing, 58 (July), 53-67.

Olkkonen, Maria E. and Juka Lipponen (2006), "Relationships Between Organizational Justice, Identification with the Organization and the Work-Unit, and Group-Related Outcomes," Organizational Behavior and Human Decision Processes, 100 (2), 202-215.

Podsakoff, Philip M. and Scott B. MacKenzie (1994), “An Examination of the Psychometric Properties and Monological Validity of Some Revised and Reduced Substitutes for Leadership Scales," Journal of Applied Psychology, 75 (5), 702-713.

Pratt, Michael G. (1998), "To Be or Not to Be: Central Questions in Organizational Identification," in Identity in Organizations, David A. Whetten and Paul C. Godfrey, eds. Thousand Oaks, CA: Sage, 171-207.

_ (2000), "Classifying Managerial Responses to Multiple Organizational Identities," Academy of Management Review, 25 (1), 18-42.

_ and Peter O. Foreman (2000), "Classifying Managerial Responses to Multiple Organizational Identities," Academy of Management Review, 25 (1), 18-42.

Quiñones, Miguel A., Kevin J. Ford, and Mark S. Teachout (1995), "The Relationship Between Work Experience and Job Performance: A Conceptual and Meta-Analytic Review," Personnel Psychology, 48 (4), 887-910.

Rapp, Adam, Raj Agnihotri, and Lukas Forbes (2008), “The Sales Force Technology-Performance Chain: The Role of Adaptive Selling and Effort," Journal of Personal Selling and Sales Management, 28 (4), 335-50.

Raudenbush, Stephen W. and Anthony S. Bryk (2002), Hierarchical Linear Models: Applications and Data Analysis Methods. Thousand Oaks, CA: Sage Publications.

Reade, Carol (2001), "Antecedents of Organizational Identification in Multinational Corporations: Fostering Psychological Attachment to the Local Subsidiary and the Global Organization," International Journal of Human Resource Management, $12(8), 1269-91$
Richter, Andreas W., Michael A. West, Rolf van Dick, and Jeremy F. Dawson (2006), "Boundary Spanners' Identification, Intergroup Contact, and Effective Intergroup Relations," Academy of Management Journal, 49 (6), 1252-69.

Riketta, Michael and Rolf van Dick (2005), "Foci of Attachment in Organizations: A Meta-Analytic Comparison of the Strength and Correlates of Workgroup Versus Organizational Identification and Commitment," Journal of Vocational Behavior, 67 (3), 490-510.

Roccas, Sonia and Marilynn B. Brewer (2002), "Social Identity Complexity," Personality and Social Psychology Review, 6 (2), 88-106.

Saxe, Robert, and Barton A. Weitz (1982), "The SOCO Scale: A Measure of the Customer Orientation of Salespeople," Journal of Marketing Research, 19 (August), 343-51.

Scott, Craig R. (1997), "Identification with Multiple Targets in a Geographically Dispersed Organization," Management Communication Quarterly, 10 (4), 491-522.

Shamir, Boas and Ronit Kark (2004), "A Single-Item Graphic Scale for the Measurement of Organizational Identification," Journal of Occupational and Organizational Psychology, 77 (1), 115-23.

Simon, Bernd and Bert Klandermans (2001), "Politicized Collective Identity: A Social Psychological Analysis," American Psychologist, 56 (4), 319-31.

Sluss, David M. and Blake E. Ashforth (2008), "How Relational and Organizational Identification Converge: Processes and Conditions," Organization Science, 19 (6), 807-823.

Stephan, Walter G. and Cookie White Stephan (1984), "The Role of Ignorance in Intergroup Relations," in Groups in Contact: The Psychology of Desegregation, Norman Miller and Marilynn B. Brewer, eds. Orlando, FL: Academic Press, 229-57.

Stroessner, Steven J. and Jason E. Plaks (2001), "Illusory Correlation and Stereotype Formation: Tracing the Arc of Research Over a Quarter Century,“ in Cognitive Social Psychology: The Princeton Symposium on the Legacy and Future of Social Cognition, G.B. Moskovitz, ed. Mahwah, NJ: Lawrence Erlbaum Associates, 247-59.

Sturman, Michael C. (2003), "Searching for the Inverted UShaped Relationship Between Time and Performance: Me`taAnalyses of the Experience/Performance, Tenure/Performance, and Age/Performance Relationships," Journal of Management, 29 (5), 609-640.

Sujan, Harish, Barton A. Weitz, and Nirmalya Kumar (1994), "Learning Orientation, Working Smart, and Effective Selling," Journal of Marketing, 58 (July), 39-52.

Swim, Janet K. (1994), "Perceived Versus Meta-Analytic Effects Sizes: An Assessment of the Accuracy of Gender Stereotypes," Journal of Personality and Social Psychology, 66 (1), 21-36.

Tajfel, Henri (1978), Differentiation Between Social Groups: Studies in the Social Psychology of Intergroup Relations. London: Academic Press.

- and John C. Turner (1979), "An Integrative Theory of Intergroup Conflict," in The Social Psychology of Intergroup Relations, William G. Austin and S. Worchel, eds. Monterey, CA: Brooks-Cole, 33-47.

— and - (1986), "The Social Identity Theory of InterGroup Behavior," in Psychology of Intergroup Relations, Stephen Worchel and William G. Austin, eds. Chicago: NelsonHall, 7-24.

Taylor, Shelley, Efrat Neter, and Heidi A. Wayment (1995), "SelfEvaluation Processes," Personality and Social Psychology Bulletin, 21 (12), 1278-87.

Thomas, James B., Shawn M. Clark, and Dennis A. Gioia (1993), "Strategic Sensemaking and Organizational Performance: Linkages Among Scanning, Interpretation, and Outcomes," Academy of Management Journal, 36 (2), 239-70. 
Thomas, Raymond W., Geoffrey N. Soutar, and Maria M. Ryan (2001), "The Selling Orientation-Customer Orientation (SOCO) Scale: A Proposed Short Form," Journal of Personal Selling \& Sales Management, 21 (1), 63-69.

Trope, Yaacov and Nira Liberman (2003), "Temporal Construal," Psychological Review, 110 (3), 403-421

Turner, John C., Michael A. Hogg, Penelope J. Oakes, Stephen D. Reicher, and Margaret S. Wetherell (1987), Rediscovering the Social Group: A Self-Categorization Theory. Worchester, UK: Billing and Sons Ltd.

Ullrich, Johannes, Jan Wieseke, Oliver Christ, Martin Schulze, and Rolf van Dick (2007), "The Identity-Matching Principle: Corporate and Organizational Identification in a Franchising System," British Journal of Management, 18 (2), 29-44.

Van Dick, Rolf, Daan van Knippenberg, Rudolf Kerschreiter, Guido Hertel, and Jan Wieseke (2008), "Interactive Effects of Work Groups and Organizational Identification on Job Satisfaction and Extra-Role Behavior," Journal of Vocational Behavior, 72 (3), 388-99.

, Ulrich Wagner, Jost Stellmaker, and Oliver Christ (2004), "The Utility of a Broader Conceptualization of Organizational Identification: Which Aspects Really Matter?" Journal of Occupational and Organizational Psychology, 77 (2), 171-91.
Van Knippenberg, Daan (2000), "Work Motivation and Performance: A Social Identity Perspective," Applied Psychology: An International Review, 49 (3), 357-71.

- and Ap Dijksterhuis (2000), "Social Categorization and Stereotyping: A Functional Perspective," European Review of Social Psychology, 11 (1), 105-144.

_ and Els C.M. van Schie (2000), "Foci and Correlates of Organizational Identification," Journal of Occupational and Organizational Psychology, 73 (2), 137-47.

Vignoles, Vivian L. and Natalie Moncaster (2007), "Identity Motives and In-Group Favouritism: A New Approach to Individual Differences in Intergroup Discrimination," British Journal of Social Psychology, 46 (1), 91-113.

Wieseke, Jan, Michael Ahearne, Son K. Lam, and Rolf van Dick (2009), "The Role of Leaders in Internal Marketing: A Multilevel Examination Through the Lens of Social Identity Theory," Journal of Marketing, 73 (March), 123-45.

Wiesenfeld, Batia M., Sumita Raghuram, and Raghu Garud (1999), "Communication Patterns as Determinants of Organizational Identification in a Virtual Organization," Organization Science, 10 (6), 777-90.

- Among Virtual Workers: The Role of Need for Affiliation and Perceived Work-Based Social Support," Journal of Management, 27 (2), 213-29. 
Copyright of Journal of Marketing is the property of American Marketing Association and its content may not be copied or emailed to multiple sites or posted to a listserv without the copyright holder's express written permission. However, users may print, download, or email articles for individual use. 